\title{
LAZER OPERÁRIO E CONSUMO CULTURAL NA SÃO PAULO DOS ANOS OITENTA*
}

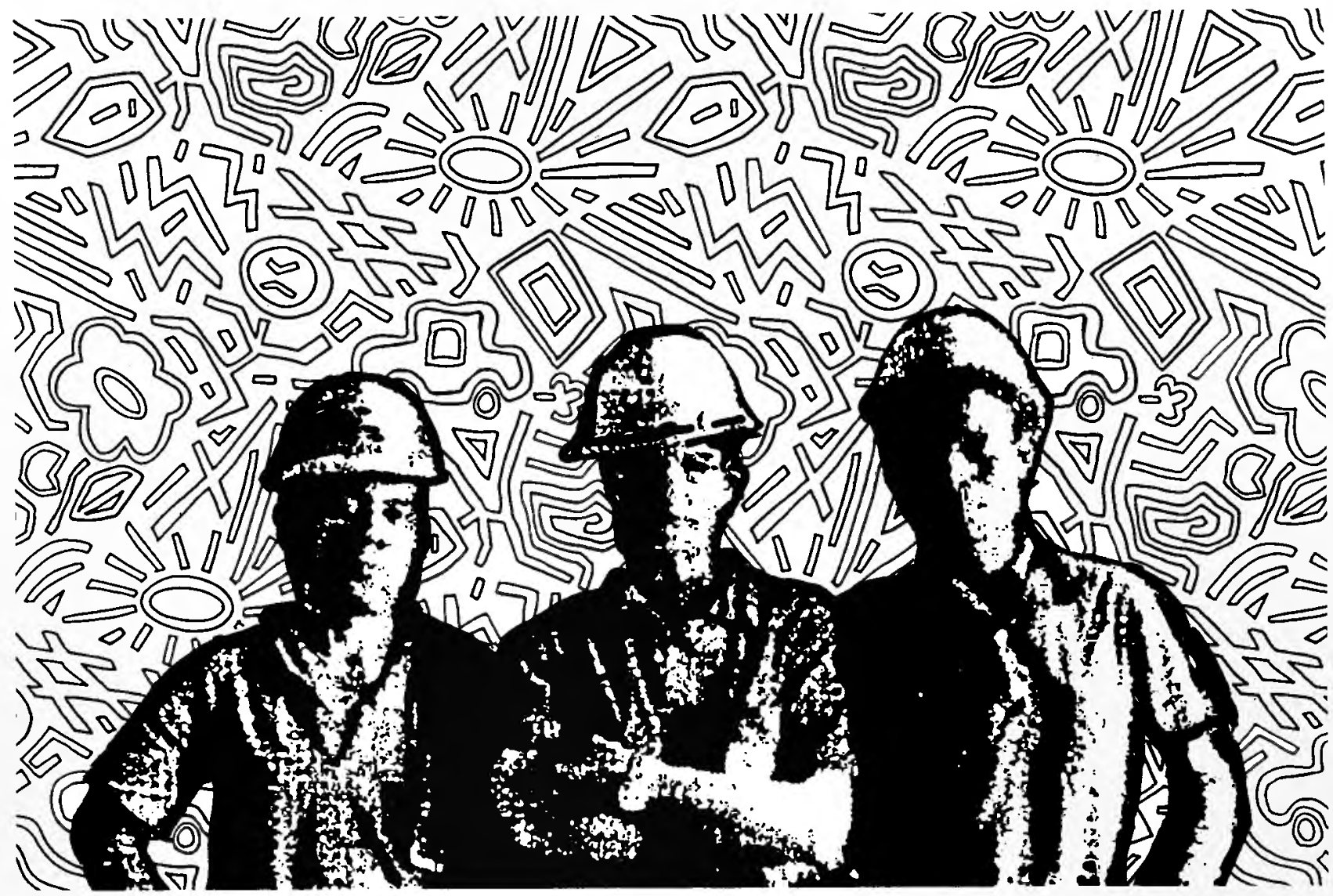

Gisela Taschner Goldenstein

Doutora em Ciências Humanas pela FFLCH/USP, Professora Adjunta do Departamento de Fundamentos Sociais e Jurídicos da Administração da EAESP/FGV e Diretora-responsável da RAE.

* RESUMO: Este artigo faz um mapeamento das práticas de lazer e das maneiras pelas quais elas são vivenciadas em uma amostra de 60 operários, selecionados por quotas cruzadas de sexo e faixa etária, residentes na região metropolitana de São Paulo nos anos oitenta. A análise incide sobre o calendário de festas e celebrações, as formas de sociabilidade, as práticas de lazer mediadas pelo mercado e o consumo cultural desses operários. E usa como referencial para comparações duas outras amostras de caracteristicas e tamanho semelhantes, de integrantes das camadas médias e da alta burguesia, respectivamente.
* PALAVRAS-CHAVE: Lazer, tempo livre, consumo cultural, indústria cultural, trabalho e lazer.

* ABSTRACT: The object of this paper is the analysis of leisure practices and their meanings in a sample of 60 workmen living in São Paulo city. Attention is focussed on their celebrations and festivities, on their sociability patterns, on their market mediated leisure practices as well as on their cultural consumption. It uses two other comparable samples, of white collars and of the bourgoisie as a framework.

* KEY WORDS: Leisure, free time uses, cultural consumption, cultural industry, labour and leisure.

\footnotetext{
* Este texto é uma versão modificada de trabalhos apresentados ao XIII Encontro Anual da ANPOCS, Caxambu, MG, outubro de 1989, e à 43a Reunião Anual da SBPC, Rio de Janeiro, julho de 1991.
} 


\section{INTRODUÇÃo}

A questão do uso do tempo livre e do lazer tornou-se objeto de atenção crescente nas sociedades capitalistas avançadas, desde que os progressos desses países de produção industrial de massas tornaram possível a redução das jornadas de trabalho e a elevação do nível de renda e de educação formal de grandes contingentes de suas populações. Ela continua na ordem do dia, e com mais peso, com a mudança da base produtiva ora em curso nessas sociedades, da industrial em série para a informatizada e flexível.

Além de ser objeto de trabalhos específicos, a preocupação com o lazer também aparece em obras que se inserem em outras áreas de especialização das ciências sociais, principalmente a sociologia do trabalho e a sociologia da cultura.

Na primeira delas, essa preocupação está presente desde em trabalhos clássicos como os de Friedmann e Naville ${ }^{1}$ até em outros bem recentes como o de Boulin e Taddei ${ }^{2}$, para fornecer apenas alguns exemplos.

Na segunda área, o lazer emerge ora como

1. Ver, por exemplo, FRIEDMANN', Georges. O trabalho em Migalhas. (1956) Trad. port: São Paulo, Perspectiva, 1972; FRIEDMANN, G. \& NAVILLE, Pierre.(orgs.) Tratado de Sociologia do Trabalho.(1961) Trad. port.: São Paulo, Cultrix/ USP, 1973.

2. BOULIN, Jean-Yves \& TADDEI, Dominique. "Os acordos de redução-reorganização do tempo de trabalho". Revista de Administração de Empresas, São Paulo, 31(2):5-24, jan./ fev./mar., 1991

3. LAZARSFELD, Paul \& MERTON Roberto K. "Comunicação de massa, gosto popular e a ação social organizada". In: COHN Gabriel.(org.) Comunicação e Indústria Cultural, São Paulo, Nacional, 1971.

4. Ver, por exemplo, ADORNO, Theodor W. Consignas. Trad. esp. Buenos Aires, Amorrortu, 1973; MARCUSE, Herbert. Ideologia da Sociedade Industrial. Trad. port. Rio de Janeiro, Zahar, 1973.

5. DUMAZEDIER, Joffre. Lazer e Cultura Popular. Trad. port. São Paulo Perspectiva, 1973. Registre-se que não há nesta introdução qualquer pretensão de fazer uma revisão bibliográfica do tema. objeto, ora como pano de fundo, ora permeando as análises na farta bibliografia existente sobre a chamada cultura de massas, em vertentes teóricas que vão desde o funcionalismo de Lazarsfeld ${ }^{3}$ até a teoria crítica de Adorno ou Marcuse ${ }^{4}$, sem deixar de mencionar o clássico Dumazedier 5 .

À parte dados provenientes de pesquisa empírica, há uma questão que permeia boa parte dos trabalhos dessas diversas áreas: a de se saber se a alienação e as limitações decorrentes dos processos de trabalho taylorizados do capitalismo industrial encontram mecanismos de compensação no momento do lazer ou se, ao contrário, elas se prolongam no tempo de não trabalho. Esta questão será também abordada no presente texto.

No Brasil, há uma grande lacuna em matéria de estudos sobre o lazer e o uso do tempo livre, por motivos óbvios: as prioridades de um país como o nosso são outras, voltadas, na maioria dos casos, para a superação de problemas já equacionados no chamado Primeiro Mundo.

Mas evidentemente, o conhecimento do uso do tempo livre é importante para se entenderem as condições de vida e o universo sócio-cultural de nossa população, seja do ponto de vista da elaboração de políticas públicas ou de empresas, seja do ponto de vista dos profissionais que atuam na área do lazer.

Nesse universo de preocupações é que se insere o presente artigo, escrito a partir da análise de alguns resultados de um estudo realizado nos anos 80 na região metropolitana da cidade de São Paulo, com o objetivo de fazer um mapeamento preliminar das práticas $\mathrm{e}$ vivências de lazer com amostras de três segmentos sócio-econômicos da população dessa cidade: operariado, alta burguesia e camadas médias. A equipe responsável por essa pesquisa incluiu, além de mim, os professores Sérgio Miceli, Maria Arminda N. Arruda e Maria Cecília S. Forjaz. Na divisão do trabalho que se fez no grupo, coube-me a responsabilidade pela parte referente aos operários e é desse segmento que vou tratar no presente texto, embora use os resultados referentes aos outros dois segmentos como referencial para comparações. A análise que será feita após a explicitação dos procedimentos técnicos incidirá primeiramente sobre o momento do trabalho e seus significados para os operários entrevistados; em seguida, abordará o uso do tempo de não trabalho e, por fim, tratará de seu consumo cultural.

\section{PROCEDIMENTOS E PERFIL DA AMOSTRA}

O lazer foi definido provisoriamente da maneira mais ampla possível, como o uso do tempo livre, pensado inicialmente como o tempo não dedicado ao trabalho remunerado. A pesquisa mostrou, no entanto, que esse tempo não pode ser recortado claramente como um tempo específico pois, de um lado, inclui uma série de atividades não remuneradas, mas necessárias ao consumo e à sobrevivência das pessoas. De outro, o lazer nem sempre se distingue como atividade que ocorra em um tempo separado rigorosamente do tempo de trabalho remunerado ou de consumo (obrigações domésticas, por exemplo). Há certas atividades que podem ter múltiplos significados e distintas formas de ser vivenciadas ao mesmo tempo. Isto será retomado mais adiante, na análise dos resultados.

A pesquisa de campo envolveu a elaboração de questionários de 101 perguntas, abertas e fechadas, que foram aplicadas a uma amostra de 180 respondentes selecionados por quotas cruzadas de segmento sócio-econômico, sexo e faixa etária e distribuídas tal como no quadro 1.

A seleção dos respondentes para cada quota foi acidental, ainda que se tenham tomado cuidados, como o de distribuir os entrevistadores pelo número mais amplo possível de locais. De qualquer maneira, as conclusões deste estudo têm sua validade restrita aos limites da amostra pesquisada. Os questionários foram aplicados em novembro e dezembro de 1984, e foram elaborados com base na análise 
Quadro 1: Estrutura da amostra

\begin{tabular}{|c|c|c|c|c|c|c|}
\hline \multirow{2}{*}{$\begin{array}{l}\text { Semmento } \\
\text { Stoto econonico } \\
\text { Sexa }\end{array}$} & \multicolumn{2}{|c|}{$\begin{array}{l}\text { A } \\
\text { mata lorg }\end{array}$} & \multicolumn{2}{|c|}{ Sel 8 nédios } & \multicolumn{2}{|c|}{ Operaties } \\
\hline & masc & fem & masc & fem & masc & fem \\
\hline $\begin{array}{l}\text { Faixa } 1 \\
20-34 \text { anos }\end{array}$ & 15 & 15 & 15 & 15 & 15 & 15 \\
\hline $\begin{array}{l}\text { Faixa } 2 \\
35-60 \text { anos }\end{array}$ & 15 & 15 & 15 & 15 & 15 & 15 \\
\hline Total da amostra & & & & & & 180 \\
\hline
\end{tabular}

dos resultados de um estudo piloto, feito previamente pela equipe, de dezoito entrevistas em profundidade, distribuídas igualmente pelos três segmentos sócio-econômicos. ${ }^{6}$

A maioria dos operários dessa amostra provém de fora da regiăo metropolitana de São Paulo, e é urbanizada (mais de $70 \%$ deles moravam em São Paulo havia mais de dez anos, no momento da coleta dos dados), mas tem menos vivência metropolitana que os respondentes dos demais segmentos, compostos, na maioria, por paulistanos. Tem um baixo nível de renda familiar (um a seis salários mínimos da época) e de educação formal (antigo curso primário). Participa pouco de atividades políticas. No que se refere à religião, a maioria se declarou católica e praticante não contumaz. Mas a participação desse grupo em atividades religiosas é maior que a verificada nos outros segmentos sócioeconômicos pesquisados.

Dos 60 respondentes operários, 52 tinham um trabalho regular no momento das entrevistas. Dos demais, seis eram esposas de operários, uma era operária aposentada e uma es- tava desempregada. Os setores em que eles trabalhavam vão dos tradicionais aos de ponta, incluindo de fábricas de fundo de quintal a multinacionais.

As funçōes que executam são, na maior parte dos casos, na própria linha de produção. Mas há desde alimentadores de máquinas até técnicos de manutenção e supervisores (encarregados). É este o seu perfil inicial.

\section{O MOMENTO DO TRABALHO}

Quanto tempo os operários entrevistados dedicam ao trabalho remunerado? Durante a semana (segunda a sexta-feira), mais da metade dos operários que estavam trabalhando dedisos). Alguns casos envolvem horas-extra, mas há outros que trabalham mais de oito horas por dia durante a semana para compensar o sábado. Outros dezenove entrevistados trabalham entre quatro e oito horas por dia. É bastante, sem dúvida. Mas a tabela 1 não permite mais classes (ver $\mathrm{X}^{2}$ e $\mathrm{P}$ ) cavam entre 8,01 e 12 horas diárias a ele $(29 \mathrm{ca}-$ concluir que trabalhem mais horas que as de-

Tabela 1: Quantas horas trabalha por dia de $2^{\mathrm{a}}$ a $6^{\mathrm{a}}$ feira $\mathrm{x}$ classe

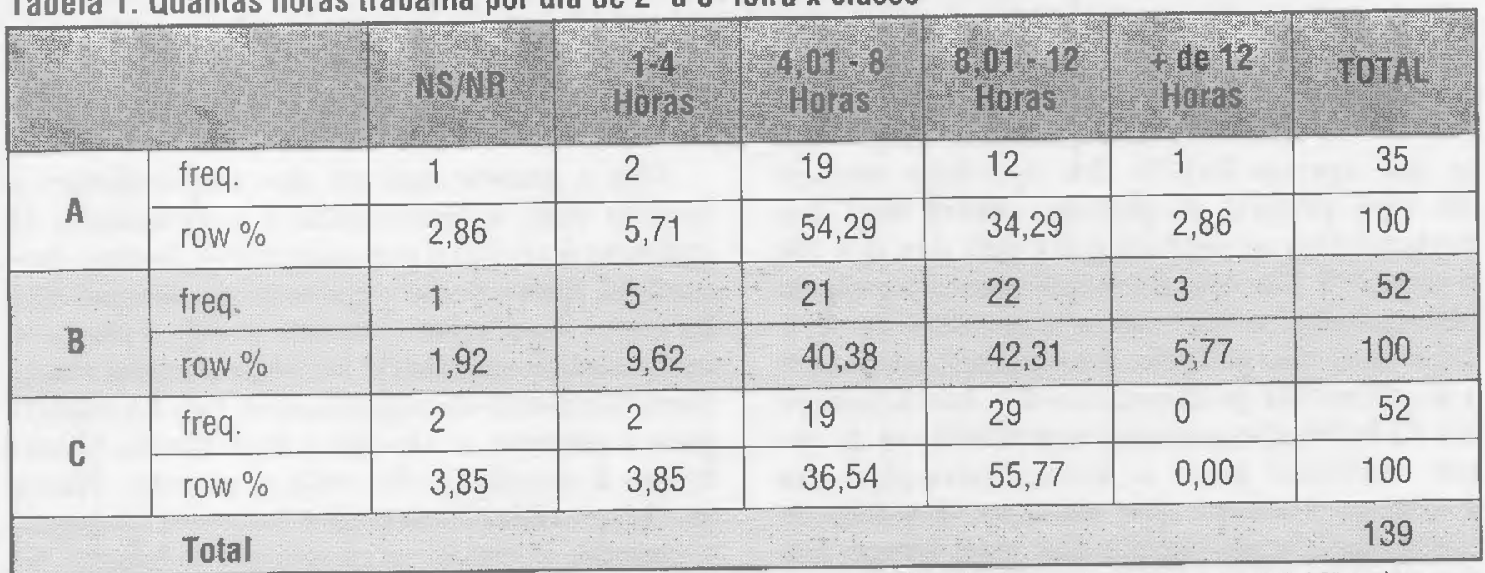

Fonte: perg. 16a: "Quantas horas, em média, o sr(a) trabalha por dia, de $2^{a}$ a $6^{\text {a }}$ feira (trabalho remunerado)?" $x$ classe; $X^{2}=8.32$ \& $P=0,2155$.

6. 0 projeto e 0 modelo de questionário dessa pesquisa, assim como os relatórios finais referentes aos segmentos operário (de minha autoria) e burguês (de autoria de Maria Cecilia S. Forjaz) estão disponiveis nos arquivos do Núcleo de Pesquisas e Publicacões da EAESP/FGV. Uma versão revista deste último foi publicada pela autora na Revista Brasileira de Ciências Sociais,2\{6), fev., 1988, sob o título "Lazer e Consumo Cultural das Elites". 
Nos fins de semana, o padrão muda, mas as comparações com as outras classes estão um pouco prejudicadas pelo fato de que quase metade dos respondentes dos setores médios (44,23\% deles) não soube precisar quanto trabalhava nos fins de semana. De qualquer maneira, as respostas à pergunta: "quantas horas trabalha por dia nos fins de semana?" permitem verificar que, embora tanto no segmento A como no $C$ a maioria não trabalhe $(77,14 \%$ dos $A^{\prime}$ s e $71,15 \%$ dos $C^{\prime}$ s não trabalham em fins de semana), entre aqueles que o fazem, os C's trabalham mais horas que os A's.

O número de horas dedicadas ao trabalho, no entanto, não significa necessariamente que os operários disponham do mesmo montante de tempo livre que os demais segmentos. Uma das razões é o tempo de transporte que provavelmente é maior, tanto pela distância como por não terem veículos próprios em sua maior parte (44 entre os 60 respondentes). Mas há outras razões.

De fato, a análise das rotinas desses entrevistados mostra que se levantam, em geral, muito cedo - exceto os que se encontram no turno da noite - antes das cinco horas da manhã, e seu dia de trabalho já começa aí. As mulheres ainda cuidam de algumas obrigações domésticas antes de se dirigirem às fábricas. Almoçam "no serviço", para o qual levam suas marmitas, ou no refeitório, em alguns casos aproveitam parte desse horário de almoço para jogar dominó ou outros jogos de salão (quando a fábrica tem este tipo de equipamento). Nos dias de semana, a rotina em casa, relatada pelos homens, após. a volta do trabalho, é jantar, tomar banho, ver um pouco de televisão e ir dormir. Para as mulheres, acrescentam-se os serviços domésticos e cuidados com as crianças, quando são casadas e têm filhos. Seu dia de trabalho é mais longo.

Nos fins de semana, além do trabalho remunerado de alguns (são minoria, como já foi visto), existem os serviços domésticos para ambos os sexos: os homens cuidam de consertos e melhorias das casas, em alguns casos participam de mutirões de autoconstrução. Notese que apenas $46,67 \%$ dos operários moram em casa própria já quitada, contra $60 \%$ dos pertencentes ao segmento B e $80 \%$ dos A's. Há mais $8,33 \%$ dos operários que têm casa própria não quitada, o que deixa um saldo de $45 \%$ deles sem casa própria. Isto explica, junto com a já conhecida problemática dos financiamentos da habitação popular, a persistência de casos voltados para a autoconstrução ${ }^{7}$. As mulheres cuidam dos serviços domésticos tradicionais e devotam a eles mais tempo nos fins de semana, posto que não têm que ir à fábrica. A faxina, por exemplo, é feita costu- meiramente neste período. Há ainda as compras para a casa, que são feitas ora pelos homens ora pelas mulheres, dependendo do arranjo de cada família. As mulheres casadas têm mais responsabilidades no serviço doméstico do que as solteiras, embora estas "ajudem", também, em diversos casos.

Assim, além do tempo formalmente devotado ao trabalho remunerado e ao transporte entre residência e local de trabalho, existem ainda as obrigações domésticas, que limitam o tempo realmente disponível para um uso mais livre, o que não significa, no entanto, que tais limites sejam rígidos. A dimensão do lazer pode eventualmente ser introduzida nos espaços do trabalho e de obrigações, através da maneira pela qual elas sejam vivenciadas. Isto pode ser entendido mais facilmente quando se verifica qual é o significado assumido pelo trabalho entre nossos entrevistados operários.

\section{O SIGNIFICADO DO TRABALHO}

Com relação ao significado do trabalho, as diferenças por sexo são muito marcantes. Mas diferenças de idade, e, entre as mulheres, o fato de ser mãe de família ou não, de ser chefe de família ou não também têm seu peso.

Entre os homens, de modo geral, o trabalho está inequivocamente associado à sobrevivência e à idéia de necessidade. Na faixa dos mais jovens, esta associação aparece de modo bem evidente (nesta faixa, dez são casados, três são solteiros, mas são chefes de família e há dois solteiros que não são responsáveis pelo sustento de outras pessoas). Há algumas poucas menções a outras dimensões do trabalho que adquirem significado:

- ao seu caráter criativo: "Trabalho é um reflexo seu", "é onde se faz alguma coisa";

- à valorização do ato de trabalhar considerado em si mesmo: "Trabalho é conhecimento", "engrandece".

Mas a grande maioria dos respondentes o associa com sobrevivência e necessidade. $O$ trabalho é vivido e pensado como destino inexorável, quase como algo natural, do qual não há como se escapar - e nem se pensa nisso independentemente de ser algo bom ou ruim. Neste universo de significados, não há espaço para a emoção, a não ser a impotência. O trabalho é condição de vida e pronto. Neste sentido, o trabalho envolve tudo: é o dinheiro, a comida, o tempo, o presente e o futuro. As falas de alguns dos operários jovens expressam com clareza essas dimensões: 
"Trabalho é uma coisa que a gente depende dele, né?"

"Trabalho é o futuro. Se não trabalha hoje, não tem garantia para amanhã."

"Trabalho é sobrevivência. Se num trabalhar num tenho nada."

"É uma grande coisa. Como sou pobre, meu trabalho é meu sustento."

"É acordar cedo e ir ganhar dinheiro."

"Uma obrigação e ao mesmo tempo uma necessidade."

"É do trabalho que vem a sobrevivência."

"Trabalho é ir lá na fábrica e fazer o que o patrão mandar. Sem poder modificar as coisas."

"Trabalho é ir na firma trabalhar."

Na faixa etária dos mais velhos, os operários do sexo masculino são todos casados e chefes de familia. Os significados encontrados em suas falas não diferem basicamente do discurso dos mais jovens.

Há umas poucas (três apenas) menções ao trabalho como realização, à dignidade que o trabalho confere:

"Trabalho é tudo aquilo que toma tempo em beneficio de alguma coisa."

"Trabalho é uma realização, uma vontade de vencer na vida, fazer as coisas certas, que os outros (o patrão) reconheçam."

"Trabalho é uma honra, viu?"

Mas predominam os significados que associam o trabalho com sobrevivência e necessidade, assim como a percepção do trabalho envolvendo tudo, confundido com a própria vida:

"Trabalho é levantar cedo, tomar ônibus, todo cidadão brasileiro tem que trabalhar para manter a familia."

"Sem o trabalho, o cara não pode viver."

"Trabalho seria uma coisa muito futurosa (sic). Precisamos disso."

"Trabalho vem a ser um divertimento. Trabalha porque precisa, mas ficar parado não dá. A gente precisa mesmo do trabalho."

"Trabalho é um dever, uma obrigação. Divertimento não é. Não é um trabalho com vontade, porque nem da para o sustento o dinheiro que a gente ganha."

"Trabalho é entrar às sete horas e sair às cinco e meia. Não importa o que vai fazer. Ficar preso das sete às cinco e meia. O pavor de ficar lá dentro $e$ não poder sair. Só na hora certa, né?"

"É tudo o que eu faço. É a própria vida, porque estou trabalhando o tempo todo."

"Trabalho é uma vida."

Para as mulheres, o significado do trabalho apresenta-se mais difuso e mais abrangente do que para os homens. Há uma série de nuances no discurso feminino que talvez reflitam diferentes situações de vida nesse universo.

A diferenciação entre o trabalho na fábrica e o trabalho doméstico é tênue, no sentido de que ambos são considerados trabalho:

"Trabalho é ir à fábrica, limpar a casa, fazer comida, lavar louça, cuidar das crianças."

Entre as chefes de familia, o trabalho assume as mesmas características de associação à sobrevivência e à necessidade observadas entre os homens:

"Trabalho é meio de sobrevivência. Sem ele a gente não faz nada."

"Trabalho é uma coisa necessária para viver."

"Trabalho é uma questão de sobrevivência, faz parte da vida."

Mas, há muitas mulheres que vêem positivamente o trabalho e, em alguns casos, lhe atribuem um caráter lúdico. As mulheres que não são chefes de familia não sentem a responsabilidade pelo sustento com a mesma contundência que os homens. O trabalho é, neste caso, uma forma de terem seu próprio dinheiro e, sobretudo, de se afastarem do confinamento doméstico.

Em outros casos, particularmente o das mães de família que também trabalham fora de casa, a dupla jornada não deixa muito tempo realmente disponível para um uso livre. Acrescentem-se a isso as limitações financeiras e poderemos entender que elas acabem vendo no trabalho fora de casa um momento de prazer. As falas seguintes ilustram essas dimensões:

"É qualquer coisa que se faça e que movimente a gente. Dependendo, deve ser pago."

"Trabalho porque gosto e não consigo ficar sem fazer nada. É também o meu sustento."

"Trabalho é animação, revigoramento, bemestar."

"Faz parte de um lazer, às vezes é chato, às vezes é bom."

"É passatempo. Gosto do que estou fazendo."

"É beneficio financeiro."

"É distração."

"É divertimento, para convivência; faz bem à saúde."

"Trabalho é tudo o que eu faço. Não tenho tempo para me divertir. Me divirto é no serviço mesmo, porque não saio para canto nenhum."

Assim, a dimensão do lazer introduz-se sorrateiramente no espaço do trabalho feminino e borram-se os limites entre os dois. 


\section{O USO DO TEMPO LIVRE}

O estudo dos momentos não ligados ao trabalho remunerado foi conduzido de modo a ouvir em primeiro lugar a fala espontânea dos entrevistados sobre o que faziam nessas horas. A partir daí, foi-se fechando o questionário, perguntando-se diretamente se faziam ou não determinadas atividades. $A$ análise seguirá este caminho também.

Durante a semana, a maioria das respostas concentra-se na seqüência: jantar, banho, TV, dormir, intercalada por serviços domésticos no caso das mulheres, como já foi dito.

Mas de um modo geral, os campeões do lazer mencionado espontaneamente são, além da TV, o hábito de fazer e receber visitas (de amigos, parentes, vizinhos) e de ficar em casa descansando, dormindo, o ócio enfim. Entre os homens, há menções freqüentes também a consertos ou construção de casa (o que não é exatamente uma atividade de lazer, mas insere-se no tempo de não trabalho remunerado), a jogar bola, sair para "dar uma volta" (muitas vezes com as crianças), a uma "cervejinha" (em casa ou no "boteco"), a jogos de mesa. As mulheres falam muito de serviços domésticos (que são realizados nesse tempo) e compras (feira); algumas referem-se a atividades religiosas e a trabalhos manuais. Os solteiros falam de sair para dançar. Cinema, em ambos os sexos, aparece em alguns casos, sempre como atividade esporádica, o que também se aplica às excursões.

As férias, a maior parte, "pega em dinheiro". Alguns nunca tiveram férias. Há menções a viagens em alguns casos, sempre com a ressalva de que vão para a casa de parentes (há apenas quatro respondentes que têm uma propriedade fora de São Paulo). Alguns homens aproveitam para "fazer bico" e ganhar algum dinheiro extra. A autoconstrução também aparece como atividade deste período, junto com o "ficar em casa".

Vejamos agora as respostas que deram quando interrogados sobre práticas mais específicas.

8. A dessacralização de inúmeras festas tradicionais, das quais o Natal seja talvez 0 exemplo mais evidente não é um fenômeno restrito ao Brasil. Joffre Dumazedier, em seu Lazer e Cultura Popular, op. cit., comenta este fenômeno na Europa e afirma que a vida moderna reelabora as festas tradicionais: a parte cerimonial entra em declínio e o carăter familiar sobrepõe-se ao religioso. Ver especialmente pp. 76-78 e 126 e seguintes.

\section{O CALENDÁRIO dE FESTAS E CELEBRAÇÕES}

Entre as datas que gostam de comemorar, as mais mencionadas pelos operários foram o Natal, o aniversário e o Ano Novo. A comparação das respostas com as dos integrantes dos setores médios e da alta burguesia mostrou que o padrão é o mesmo em todas as classes, no que se refere a Natal e aniversário. Com relação ao Ano Novo, o segmento $B$ lhe deu menos importância que os outros. As diferenças por sexo, levando-se em conta a amostra total não apresentaram relevância; já no cruzamento por faixa etária, embora o Natal e $o$ aniversário apareçam em ambas as faixas como as datas mais mencionadas, entre os mais velhos o número de pessoas que disse não gostar de comemorar nenhuma festa foi maior do que os que mencionaram o Ano Novo.

E como comemoram essas datas? O Natal é uma festa típica e essencialmente familiar nas três categorias sócio-econômicas. Entre os operários, há muitas menções a uma "comida melhor". Mas mesmo os que não podem se dar a este "luxo" passam a data junto à família. Nem todos mencionam presentes e há somente quatro referências a atos religiosos ${ }^{8}$. Há apenas cinco entrevistados que dizem que não comemoram o Natal.

O Ano Novo é celebrado entre os operários em um esquema semelhante ao do Natal, isto é, em família, só que tem uma abertura para os amigos e vizinhos também. As diferenças de classe aí pesam mais do que no Natal, no sentido de que as demais classes dispersam-se entre um maior número de alternativas, onde ressalta a de viajar e a de se participar de uma festa de réveillon fora de casa. $O$ padrão contrasta especialmente com o do segmento $\mathrm{A}$. $\mathrm{O}$ sexo, na amostra total, não tem relevância para explicar diferenças; a idade talvez tenha algum peso, no sentido de que é ligeiramente maior o número de viagens entre os mais jovens e maior o número de mais velhos que fazem uma comemoração familiar.

No que se refere aos aniversários, há uma distinção que merece ser feita, pelo menos entre os operários: o aniversário das crianças tende a ser comemorado com mais freqüência do que os dos adultos. Com relação ao aniversário do próprio entrevistado ou de seu cônjuge, $46,7 \%$ disseram que não os comemoram, $45 \%$ deles disseram que o fazem e $8,3 \%$ deles não responderam à questão. A maneira de comemorar implica um "bolinho", cerveja, refrigerantes, a reunião da família e eventualmente de amigos, "nada muito caro". Este padrão operário difere do encontrado nos demais segmentos, como era previsível: apenas $9,7 \%$ da burguesia e $21,7 \%$ dos respondentes dos setores médios declararam não fazer comemoração alguma.

O hábito de jantar ou almoçar fora, como forma de comemoração, parece também estranho ao universo dos que não pertencem ao segmento A. Já os aniversários dos filhos, a grande maioria dos respondentes operários ( $84,6 \%$ dos que têm filhos) disse costumar comemorá-los. Aí fala-se em "festinha", bolo, às vezes em balões, sucos e refrigerantes, convidam-se algumas crianças, a família e vizinhos. Nem todas as comemorações têm todos 
estes componentes (muitas vezes, a referência é apenas a bolo e crianças) e nem todas são feitas regularmente (comemora-se "quando a situação - dinheiro - permite"). Ainda assim, o aniversário das crianças parece receber maior atenção do que o dos adultos. Observese que a menção espontânea a presentes foi muito rara.

O carnaval foi também lembrado (embora com menos freqưuência do que as três datas acima examinadas) como festa que se gosta de comemorar. Indagados sobre o que faziam habitualmente neste período, no entanto, a maior parte dos operários afirmou não participar ativamente desta festa. Muitos ficam em casa e a acompanham pela TV, as viagens são poucas e alguns trabalham normalmente nestes dias, sem falar dos que não gostam da festa. Não chegam a $20 \%$ os que desfilam em escolas de samba ou "pulam" na rua ou em clubes, o que não deixa de ser um pouco surpreendente numa data que é vista correntemente como a de uma festa essencialmente popular.

O domingo é também uma data importante, por ser basicamente um dia de convivência familiar. A tabela 2 mostra que, entre os operários, $80 \%$ almoça com a família (e a tabulação manual mostra que isto ocorre geralmente em casa e não em restaurantes); $15 \%$ deles incluem, além da família, os namorados e amigos nestes almoços. Esta tabela mostra também que tal padrão é o mesmo que prevalece nos demais segmentos sócio-econômi$\cos$ (com exceção do local em que esses almoços ocorrem, sobre o qual só temos informações para a classe operária) com uma impressionante uniformidade. Se se pode pensar em um hábito cultural brasileiro, está aí um que não deixa margem a dúvidas.

A convivência com familiares e amigos, contudo, não é um hábito reservado a algumas datas especiais. Entre os operários, é um fato de grande freqüência: $80 \%$ deles visita ou recebe parentes em sua casa sem ser em dias de festa. $O$ sexo e a idade não influem neste as pecto. Com relação aos amigos, só $16,7 \%$ deles não os costuma receber. Recebem os próprios amigos e os de outros membros da família, nem que seja "às vezes" (13,3\% dos operários), independentemente de sexo e de idade, como no caso dos parentes; receber e fazer visitas a parentes e amigos parece ser também um hábito forte em todas as classes, o que pode ser facilmente verificado no exame das tabelas 3 e 4.

Nelas vê-se que as distribuições seguem um padrão semelhante nos três segmentos sociais. O que talvez seja específico dos entrevistados da classe operária é o peso relativo que esta prática tem no conjunto do uso do seu tempo, em contraste com o leque muito mais amplo de alternativas utilizadas pelos membros das outras classes. Observe-se também que a prática de visitas em períodos que cubram o horário das refeiçōes é viabilizada, de acordo com o que verificamos nas entrevistas em profundidade realizadas na etapa anterior desta pesquisa, através de uma socialização não explícita de custos, a qual se consubstancia no hábito de a visita sempre "trazer al-guma coisa", isto é, alguma quantidade de alimento.

O exercício intensivo de uma sociabilidade direcionada a amigos, mas principalmente a familiares e vizinhos, faz parte de um estilo de vida comumente atribuído a comunidades do interior, e a um universo que tende a perder espaço nas metrópoles do mundo industrializado, em que o uso do tempo, inclusive o do tempo livre, tende a ser cada vez mais mediado pela mercantilização e pontuado pelo ritmo do trabalho industrial.

Tabela 2: Com quem almaça aos domingos $\mathrm{x}$ classe

\begin{tabular}{|c|c|c|c|c|c|c|c|c|}
\hline & & istir & Framitia & $\begin{array}{l}\text { Amigos } \\
\text { Namorado }\end{array}$ & Sozinho & $\begin{array}{l}\text { Fam. Amio } \\
\text { VIamorado }\end{array}$ & Outros & TOMAL \\
\hline \multirow{2}{*}{ A } & freq. & 1 & 46 & 2 & 1 & 8 & 2 & 60 \\
\hline & row $\%$ & 1,67 & 76,67 & 3,33 & 1,67 & 13,33 & 3,33 & 100 \\
\hline \multirow{2}{*}{ B } & freq. & 0 & 46 & 5 & 1 & 5 & 3 & 60 \\
\hline & row $\%$ & 0 & 76,67 & 8,33 & 1,67 & 8,33 & 5,00 & 100 \\
\hline \multirow{2}{*}{ C } & freq. & 0 & 48 & 1 & 1 & 9 & 1 & 60 \\
\hline & row $\%$ & 0 & 80,00 & 1,67 & 1,67 & 15,00 & 1,67 & 100 \\
\hline \multicolumn{8}{|c|}{ Total } & 180 \\
\hline
\end{tabular}

Fonte: perg. 42: "Onde e com quem almoça aos domingos?" $x$ classe 
Tabela 3: Costume de receber ou visitar parentes sem ser em dias de festa $\mathrm{x}$ classe

\begin{tabular}{|c|c|c|c|c|c|}
\hline & & $\sin$ & $\mathrm{NaO}$ & As vezes & TOTAL \\
\hline \multirow{2}{*}{ A } & freq. & 35 & 12 & 13 & 60 \\
\hline & row $\%$ & 58,33 & 20,00 & 21,67 & 100 \\
\hline \multirow{2}{*}{ B } & freq. & 30 & 13 & 17. & 60 \\
\hline & row $\%$ & 50,00 & 21,67 & 28,33 & $100^{\circ}$ \\
\hline \multirow[t]{2}{*}{ C } & freq. & 35 & 12 & 13 & 60 \\
\hline & row $\%$ & 58,33 & 20,00 & 21,67 & 100 \\
\hline \multicolumn{5}{|c|}{ Total } & 180 \\
\hline
\end{tabular}

Fonte: perg. 44: "Costuma receber ou visitar parentes sem ser em dias de festa?" $x$ classe

Tabela 4: Costume de receber ou visitar amigos sem ser em dias de festa $\mathrm{x}$ classe

\begin{tabular}{|c|c|c|c|c|c|c|c|}
\hline & & $\begin{array}{l}\text { Sim Aníg } \\
\text { Entrevis }\end{array}$ & $\begin{array}{l}\text { Sim Amig: } \\
\text { Outros }\end{array}$ & $\begin{array}{l}\text { Sin Rnilg } \\
\text { Ent. e out }\end{array}$ & Não & Hsw veres & TOTAL \\
\hline \multirow{2}{*}{ A } & freq. & 10 & 4 & 32 & 4 & 10 & 60 \\
\hline & row $\%$ & 16,67 & 6,67 & 53,33 & 6,67 & 16,67 & 100 \\
\hline \multirow{2}{*}{ B } & freq. & 14 & 0 & 22. & 14 & 10 & 60 \\
\hline & row $\%$ & 23,33 & 0,0 & 36,67 & 23,33 & 16,67 & 100 \\
\hline \multirow{2}{*}{ c } & freq. & 14 & 7 & 21 & 10 & 8 & 60 \\
\hline & row $\%$ & 23,33 & 11,67 & 35,00 & 16,67 & 13,33 & 100 \\
\hline \multicolumn{7}{|c|}{ Total } & 180 \\
\hline
\end{tabular}

Fonte: perg. 48: "Visita ou recebe amigos sem ser em dias de festa?" $x$ classe

Apenas para dar alguns exemplos, poderíamos mencionar referências de Adorno 9 e de Braverman ${ }^{10}$ a este processo. O primeiro, ao mostrar a lógica mercantil invadindo e subjugando tendencialmente todas as dimensões

9. ADORNO, Theodor W. fala Ver especialmente seu ensaio "Tiempo Livre", In: Consignas, op. cit. 0 tempo livre, ao contrário de seu próprio conceito. tende a transformar-se em paródia de si mesmo ( $p .55)$

10. BRAVERMAN, Harry. Trabalho e Capital Monopolista. Trad. port.: Rio de Janeiro, Zahar, 1980, especialmente cap. 13, "0 mercado Universal".

11. Não estamos ignorando o fato arquiconhecido de que a familia nuclear tende a substituir a familia extensa. Estas consideraçōes falam tanto da convivência no interior da familia nuclear como no interior do que restou da extensa. velhos e as crianças, antes a cargo da família e agora em mãos de asilos, casas de repouso, creches e escolas para crianças desde a mais tenra idade. Neste processo esboroam-se os espaços para uma convivência familiar mais intensa e prolongada, a qual vai ficando circunscrita a ocasiões cada vez mais restritas e muitas vezes predeterminadas pelo calendário ${ }^{11}$

Em nossa pesquisa, tais tendências modernizantes revelaram pouca força. A família aparece em todas as classes com muito peso e a convivência com ela e vizinhos é especialmente marcante entre os entrevistados operários. Os locais de residência de grande parte dos entrevistados são bairros afastados do centro da cidade de São Paulo e ali se reproduz - até na arquitetura de alguns deles, com suas igrejas defronte a praças, onde o footing ainda pode ser visto e as quermesses apontam de quando em quando - um estilo de vida mais tradicional, onde ainda há espaço para as conversas no portão, para sair para ir 
até a praça dar uma volta, e até para ficar em casa sem fazer nenhuma atividade específica, como apareceu nas menções espontâneas dos respondentes, além do convívio familiar.

A vivência urbano-industrial relativamente mais recente, assim como a escassez de recursos econômicos, de educação formal e, paradoxalmente, até de tempo realmente livre que dificulta $o$ acesso a outras formas de fruição de lazer disponíveis para outras classes sociais - certamente atuam, no caso dos operários, no sentido de manutenção desses padrões mais antigos.

As considerações que acabam de ser feitas ganham mais consistência à medida que se examina a participação dos entrevistados ope rários em outras formas possíveis de uso do tempo de não trabalho.

\section{CONSUMO CULTURAL E DE INDÚSTRIA CULTURAL}

Nesta rubrica, inclui-se a freqüência a cinemas, teatros, concertos, shows, a leitura de jornais, revistas e livros, a audição de rádio, discos e fitas, e a televisão.

Com relação ao cinema (conforme respostas à pergunta: costuma ir ao cinema?), $60 \%$ dos entrevistados operários não costumam ir. Só cinco respondentes deste segmento afirmam ir regularmente, uma vez por semana; e $18,3 \%$, disseram ir uma ou duas vezes ao mês. Este padrão contrasta bastante com o de outras classes: como se pode ver na tabela 5, apenas $21,7 \%$ dos respondentes de classe B e $15 \%$ dos de classe $A$ declararam que não costumam ir a cinemas. As diferenças de idade, ao contrário das de sexo, são relevantes (não só entre os operários): há uma proporção de quase dois freqüentadores jovens para cada freqüentador mais idoso; trata-se, pois, de uma atividade muito mais típica de jovens do que de velhos (no caso dos operários, o $X^{2}$ para diferenças por idade foi de 9,032 , com $P=0,029$, significante, portanto; já para diferenças por sexo, $X^{2}=1,518$ com $P=0,678$, não significante).

A companhia escolhida para ir ao cinema (entre os que vão, evidentemente) mostra que não se trata de um hábito ligado à convivência familiar. De fato, a quase totalidade dos frequientadores operários costuma ir com o(a) namorado(a) ou cônjuge e houve um único entrevistado que respondeu que costuma ir com a familia. Este padrão não difere do verificado nas demais classes.

Quanto aos gêneros de filme preferidos, entre os operários que costumam ir ao cinema, o filme "romântico" ganhou longe, com doze menções (das quais, nove femininas), seguido pelos de tipo "faroeste", "de sexo" (seis menções cada, quase todas masculinas) e "comédia" (seis menções, também, quatro femininas e duas masculinas). Registre-se, de passagem, que a tabulação desta questão para o conjunto da amostra revelou-se problemática, não permitindo a comparação com as preferências das demais classes sociais, mas ela permite ver que as preferências dos operários não seguem o padrão do conjunto da amostra.

Concluindo, com relação aos operários, o hábito de ir ao cinema existe neste grupo, mas tem uma presença muito mais fraca que nas demais classes. Fintre os que frequientam as salas de cinema, a grande maioria é composta de jovens, certamente mais permeáveis aos hábitos mais urbanos e metropolitanos do que as gerações mais velhas. Isto é coerente com o fato de que se costuma ir ao cinema com o cônjuge/namorado(a), mais do que com outros membros da família ou com o conjunto dela. ${ }^{12}$

Tabela 5: Freqüência a cinemas $x$ classe

\begin{tabular}{|c|c|c|c|c|c|c|}
\hline 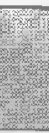 & & Nāo & $\begin{array}{l}\text { Trez por } \\
\text { Semana }\end{array}$ & $\begin{array}{l}1 \text { ou } 2 \\
\text { por Mês }\end{array}$ & $\begin{array}{l}\text { 1 vez } \\
\text { porthes }\end{array}$ & FOTAL \\
\hline \multirow{2}{*}{ A } & freq. & 9 & 14 & 25 & 12 & 60 \\
\hline & row $\%$ & 15,00 & 23,33 & 41,67 & 20,00 & 100 \\
\hline \multirow{2}{*}{ B } & freq. & 13 & 10 & 18. & 19 & 60 \\
\hline & row $\%$ & 21,67 & 16,67 & 30,00 & 31,67 & 100 \\
\hline \multirow{2}{*}{ C } & freq. & 36 & 5 & 11 & 8 & 60 \\
\hline & row $\%$ & 60,00 & 8,33 & 18,33 & 13,33 & 100 \\
\hline \multicolumn{6}{|c|}{ Total } & 180 \\
\hline
\end{tabular}

Fonte: perg. 45: "Costuma ir ao cinema?" x classe

12. Esta associacão entre tradiçāo rural e pouca frequêência ao cinema é constatada por Dumazedier na França, no livro citado na nota 5 . Diz ele: "A tradição pode opor uma recusa a modernização do lazer. Por exemplo, em meios rurais é quase nula a freqüência a cinemas... Dos $48 \%$ de franceses que não vão a cinemas, $61 \%$ vivem em comunas de menos de dois mil habitantes e assim estariam prejudicados pela distância ou pela carência de equipamentos cinematográficos; porém, $30 \%$ moram em cidades de mais de 100 mil habitantes e freqüentemente são originários da zona ruraf' (conf. p.74 e nota de rodapé $\Pi^{0} 7$ ). 
Suas preferências talvez apresentem certa especificidade de classe, gostando as mulheres mais dos filmes românticos e os homens dos de faroeste e dos "de sexo" (dissemos talvez, porque a tabulação para o conjunto da amostra não está perfeita). Deve-se lembrar que, à parte o possível peso do caráter urbano do cinema, entre os operários há um outro elemento que pode atuar como fator inibidor de sua freqüência, além, no caso de famílias que vivem nos limites da sobrevivência, do preço: trata-se do fato de que grande parte dos filmes no Brasil são estrangeiros e exigem uma capacidade de leitura relativamente rápida para que se possa acompanhar a velocidade dos letreiros que se superpóem às imagens e isto pode ser um grande problema para um contingente marcado por uma educação formal tão precária, quando não totalmente ausente.

Com relação ao teatro, trata-se de uma atividade que definitivamente não está incorporada aos hábitos operários. $85 \%$ deles não costumam freqüentá-lo, nem "de vez em quando", em contraste com uma proporção de apenas $33,3 \%$ dos respondentes dos setores médios e $10 \%$ dos da alta burguesia. É uma prática associada à estratificação social, sem qualquer sombra de dúvida, entre nossos respondentes o que, de resto, não constitui qualquer surpresa.

Os concertos revelaram-se um universo ainda mais excludente que os teatros: $93,3 \%$ dos operários não os costumam freqüentar. Esta proporção cai para $73,3 \%$ entre os respondentes dos setores médios e para $48,3 \%$ dos da alta burguesia. Já os shows musicais são um pouco mais acessiveis, ainda que $75 \%$ dos operários não os costumem freqüientar; na classe B e na A, esta porcentagem cai para $46,7 \%$ e $15 \%$ respectivamente. A freqüência a concertos e shows está, pois, também, nitidamente associada à estratificação. Isto não significa que não haja interesse por música entre os operários, ao menos pela música popular.

De fato, $43,3 \%$ dos respondentes operários costumam ouvir discos e/ou fitas sempre e mais $30 \%$ deles óuvem às vezes; apenas $25 \%$ dos operários declararam que não costumam ouvir discos nem fitas. A porcentagem dos respondentes que não costumam ouvir nenhum dos dois cai para $10 \%$ nos setores médios e para apenas $1,67 \%$ na alta burguesia. Mas, ainda que ouçam menos que os dos demais segmentos sociais, aproximadamente $3 / 4$ (quase $75 \%$ ) dos respondentes opexários têm este hábito. Isto pode ser visto na tabela 6 .

Registre-se também que as diferenças de sexo não são relevantes neste caso, mas as de idade têm algum peso: embora o número dos que ouvem às vezes seja mais ou menos semelhante em todas as idades, a maioria dos respondentes que declararam que não costumam ouvir têm 35 anos ou mais; reversivamente, a maioria dos que disseram ouvir sempre tem menos de 35 anos. Isto ocorreu em todas as classes sociais. No caso dos operários, o $X^{2}$ para diferenças de idade foi de 11,75 , com $\mathrm{P}=0,008$ (significante, portanto). $\mathrm{O}$ hábito de ouvir música através de discos ou fitas é, pois, mais dos jovens; e ainda que aumente à medida que se sobe na escala social, ele atravessa todas as classes e é algo consagrado mesmo entre os operários. E boa parte deles dispõe de equipamentos domésticos para isto. Nesta amostra, foram arrolados entre eles 21 toca-fitas, 20 gravadores e 23 aparelhos de som ou vitrolas, o que dá em média cerca de um aparelho por entrevistado. Isto sem mencionar outros equipamentos como rádio e TV, de que falaremos mais adiante.

Além de gostarem de ouvir música, alguns tocam um (ou mais de um) instrumento musical. São poucos, é verdade, apenas treze (ou seja, $21,66 \%$ deles), mas esta proporção não é

Tabela 6: Costume de ouvir discos/fitas $\mathrm{x}$ classe

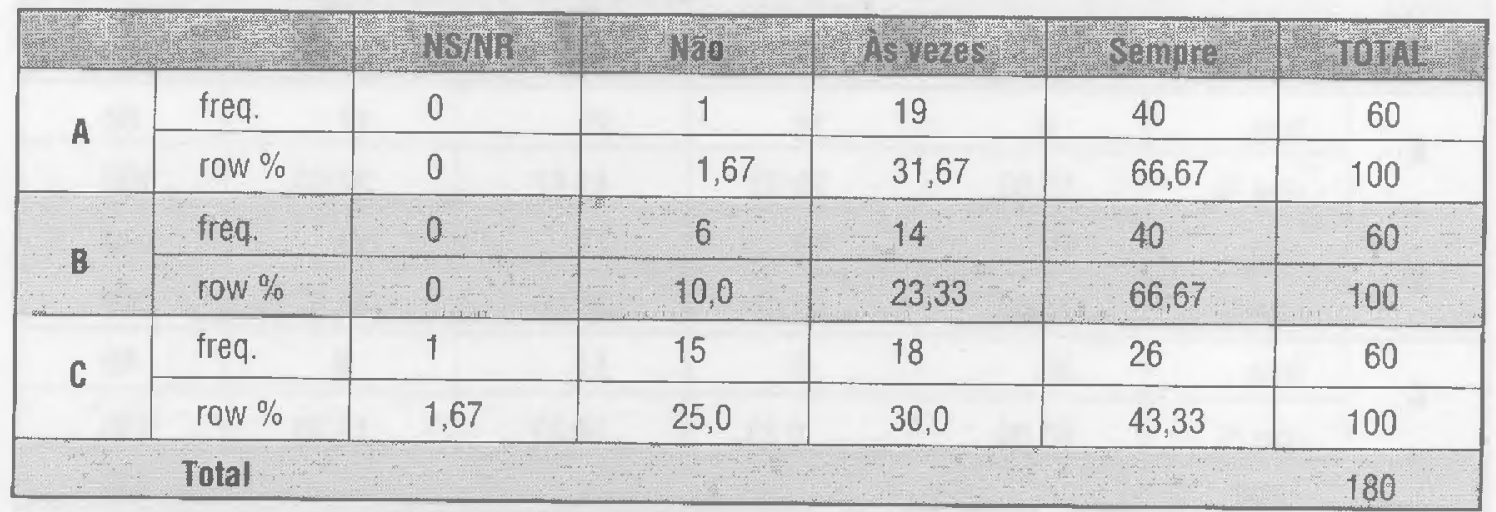

Fonte: perg. 91: "Costuma ouvir discos/fitas? "x classe 
diferente da verificada nos demais segmentos sociais.

Quanto aos gêneros musicais mais apreciados, não foi possível obter uma tabulação exata que permitisse comparar as preferências de cada segmento sócio-econômico. Mas entre os operários, os mais mencionadas foram "música popular brasileira", "romântica" e "sertaneja", nesta ordem. E na distribuição de frequiência para o total da amostra $(N=180)$ os mais mencionados foram "música popular brasileira", "popular estrangeira", "erudita" e "romântica", nesta ordem, o que dá alguma especificidade ao gosto operário.

Da mesma maneira, quando foram indagados sobre os cantores prediletos, entre os operários, Roberto Carlos recebeu, de longe, o maior número de menções, sem diferenças de sexo. Os cantores brasileiros são os mais mencionados em todas as classes. Mas à medida que se sobe na escala social, os cantores estrangeiros ganham espaço cada vez maior.

Isto reforça a possível especificidade do gosto operário (se é que se pode falar de algo assim ${ }^{13}$ ) ou, eventualmente, a hipótese da dificuldade de acesso a gêneros musicais que exigem maior educação musical ou maior exposição ao que nos anos sessenta se costumava chamar de imperialismo cultural.

Finalmente, cabe assinalar que cerca de $1 / 3$ dos operários costuma ir, embora não se saiba com que periodicidade, a lugares onde se possa dançar. E uma proporção menor que a existente nas demais classes - na distribuição de freqüência para o total (180) da amostra, esta proporção é de $51,66 \%$.

No caso dos operários, as diferenças por sexo não existem; já as de idade têm peso, pois é entre os jovens que se encontra a maior parte dos frequientadores de locais dançantes. Registre-se também que os "bailes" são, de longe, os locais dançantes mais mencionados.

Levando-se em conta o que foi dito até aqui, não parece haver exclusão completa dos operários do universo musical, nem que a exclusão existente seja fruto da presença de uma cultura ou subcultura à parte, a impedir pura e simplesmente a absorção do novo, mesmo que algumas de suas características possam atuar nessa direção. Suas preferências denunciam raízes rurais ainda atuantes, apreciam menos a música estrangeira do que a nacional; mas não se pode inferir daí que se trate de um gosto infenso, de modo geral, às manifestações da moderna indústria cultural, como fica evidente pela popularidade de cantores como Roberto Carlos entre eles. Eles participam do universo musical em suas modalidades mais acessíveis, em termos de dinheiro e de requisitos de educação formal. De qualquer maneira, sua participação acaba sendo muito menor e mais pobre do que aquela que os demais segmentos sociais incluídos em nosso estudo podem ter.

Vejamos agora como se situam os operários face ao hábito de leitura no seu tempo de não trabalho. Convém apenas ponderar que como este hábito é muito valorizado socialmente, é de se esperar que as declarações dos respondentes levem a números inflacionados de leitores, em todas as camadas sociais. Tentamos minimizar o viés que pode daí decorrer, cercando este tema por diversos lados, que vão desde a especificação dos objetos de leitura até, em alguns casos, de sua freqüência.

Com relação aos jornais, apesar disto, apenas $16,67 \%$ dos operários declararam costumar lê-los diariamente, em contraste com $53,33 \%$ dos respóndentes dos setores médios e com $83,33 \%$ dos de alta burguesia. Levando-se em conta, além destes, os respondentes que declararam ler os jornais nos finais de semana e considerando-se a soma destes dois grupos como o conjunto de leitores regulares, veremos que o contraste com as outras classes se mantém: teremos como leitores regulares $28,34 \%$ dos operários, $68,33 \%$ dos setores médios e $90 \%$ dos de alta burguesia. A leitura de jornais, portanto, cresce à medida que se sobe na escala de estratificação sócio-econômica (a qual, como é amplamente sabido, é acompanhada pela de educação formal, inclusive nesta amostra). Isto não constitui surpresa e pode ser verificado na tabela 7 . Aí se vê também que a porcentagem dos operários que declararam que nunca lêem jornais é maior do que a dos que se disseram leitores diários e semelhante à do conjunto que denominamos aqui de leitores regulares, em contraste com as respostas dos demais segmentos sociais. As categorias "de vez em quando" e "raramente", por sua vez, são aquelas em que se espera maior camuflagem de ausência de leitura, por serem as mais evasivas. Por isso não as usaremos diretamente para efeitos de aferição de leitura. Assim mesmo, note-se que nestas categorias, especialmente na primeira delas, concentra-se o maior número de respostas dos operários e um número razóavel das dos setores médios.

Além de perguntarmos diretamente se costumavam ler jornais, procuramos saber se havia o hábito de comprá-los.

Com relação a assinaturas, de acordo com as respostas obtidas, 96,7\% dos operários declararam que não assinam nenhum jornal, em contraste com $50,8 \%$ dos de classe $B$ e $2,9 \%$ dos de classe A. Mas aí é preciso fazer duas ordens de considerações. A primeira delas é que a assinatura implica em pagar adiantado pelos
13. Sobre o problema do gosto popular também já se escreveu bastante, especialmente os críticos da chamada cultura de massas. Ver, a título de exemplo, o clássico ensaio já mencionado de LAZARSFELD Paulo \& MERTON, Robert K. Em outra linha, ver BOURDIEU, Pierre. La distinction: critique sociale du jugement. Paris, Editora de Minuit, 1979 
Tabela 7: Hábito de ler jornais $\mathrm{x}$ classe

\begin{tabular}{|c|c|c|c|c|c|c|c|}
\hline & & $\begin{array}{l}\text { Sim Dla - } \\
\text { ramente. }\end{array}$ & $\begin{array}{l}\text { Sim Fins } \\
\text { de Semana }\end{array}$ & $\begin{array}{c}\text { De vez } \\
\text { em Quando }\end{array}$ & Paramente & N56 & TOTAL \\
\hline \multirow{2}{*}{ A } & freq. & 50 & 4 & 6 & 0 & 0 & 60 \\
\hline & row $\%$ & 83,33 & 6,67 & 10,00 & 0 & 0 & 100 \\
\hline \multirow{2}{*}{ B } & freq. & 32 & 9 & 14 & 4 & 1 & 60 \\
\hline & row $\%$ & 53,33 & 15,0 & 23,33 & 6,67 & 1,67 & 100 \\
\hline \multirow{2}{*}{ C } & freq. & 10 & 7 & 20 & 7 & 16 & 60 \\
\hline & row $\%$ & 16,67 & 11,67 & 33,33 & 11,67 & 26,67 & 100 \\
\hline \multicolumn{7}{|c|}{ Total } & 180 \\
\hline
\end{tabular}

Fonte: perg. 78: "0 Sr. (a) costuma ler jornais? " $x$ classe

jornais a serem lidos durante um certo período $\mathrm{e}$ isto pode se tornar impraticável para familias de renda mais baixa, dado o volume de dinheiro que tem de ser gasto de uma só vez. A segunda é que na época em que os dados foram coletados, os jornais mais populares (geralmente, vespertinos) não faziam vendas pelo sistema de assinaturas.

A questão da compra dos jornais em bancas pode ser vista na tabela 8 , que mostra que apenas $15 \%$ dos operários declararam que os compram diariamente (numa proporção coerente com a dos que declararam lề-los diariamente) e mais $6,67 \%$ disseram comprá-los em fins de semana. Nela se vê também que $43,33 \%$ deles afirmou que não os compra (sem falar da zona mais nebulosa dos $35 \%$ que dizem comprar de vez em quando) e esta categoria de não compradores é a que concentra o maior número de respostas. É verdade que nos seg- mentos $\mathrm{A}$ e $\mathrm{B}$ há também alto número de respondentes que não compram jornais nas ban cas. Mas acabamos de ver que cerca de metade dos B's e a quase totalidade dos A's os assina, o que não ocorre com os C's.

Quanto aos temas de maior interesse nos jornais, a tabela 9 mostra que os esportes são o assunto mais mencionado, seguido pelo noticiário policial e por variedades e política nacional. Vê-se aí também que há diferenças de sexo na determinação de algumas preferências: os esportes aparecem como tema mais masculino, ao contrário da seção de variedades (e da própria "seção feminina"); as notas policiais, por sua vez, atraem tanto homens como mulheres. Os dados desta tabela referem-se apenas aos operários. Não temos disponivel uma tabulação para os demais segmentos em separado, mas na distribuição de freqüência para o total da amostra (180), os

\section{Tabela 8: Compra de jornais em bancas $\mathrm{x}$ classe}

\begin{tabular}{|c|c|c|c|c|c|c|c|}
\hline & & NSNIR & Nabo: & $\begin{array}{l}\text { Diarta } \\
\text { mente }\end{array}$ & $\begin{array}{l}\text { Fins de } \\
\text { Semana }\end{array}$ & $\begin{array}{c}\text { Devez } \\
\text { en Quando }\end{array}$ & TOTAL \\
\hline \multirow{2}{*}{ A } & freq. & 0 & 28 & 12 & 3 & 17 & 60 \\
\hline & row $\%$ & 0 & 46,67 & 20,00 & 5,00 & 28,33 & 100 \\
\hline \multirow{2}{*}{ B } & freq. & 1 & 18 & 13 & 11 & 17 & 60 \\
\hline & row $\%$ & 1,67 & 30,00 & 21,67 & 18.33 & 28,33 & 100 \\
\hline \multirow{2}{*}{ C } & freq. & 0 & 26 & 9 & 4 & 21 & 60 \\
\hline & row $\%$ & 0 & 43,33 & 15,00 & 6,67 & 35,00 & 100 \\
\hline \multicolumn{7}{|c|}{ Total } & 180 \\
\hline
\end{tabular}

Fonte: perg. 82: "0 Sr. (a) ou alguém na sua casa tem o hábito de comprar jornais nas bancas? " $x$ classe 
temas mais mencionados, em ordem decrescente, são: política nacional, economia, esportes c política internacional, seção cultural, o que mostra uma outra ordem de prioridades de leitura fora da classe operária.

Os esportes e as variedades (os temas mais mencionados pelos homens e pelas mulheres, respectivamente, na classe operária) são justamente aquilo que alguns estudiosos da imprensa, como por exemplo, Pierre Albert, chamam de páginas-revista. Elas foram se desenvolvendo, na história da imprensa, na medida em que os custos de produção industrial dos jornais lam caindo (em razão de inovações tecnológicas) em alguns países (como França e Inglaterra, por exemplo) e os jornais, ao se tor- narem mais baratos, passaram também a diversificar suas seções, de modo a interessar e incorporar como leitor um conjunto da população que não tinha ainda o hábito de ler jornais ${ }^{14}$.

Esta foi uma das maneiras pelas quais a imprensa foi ganhando um público de massas e a indústria cultural foi se formando ${ }^{15}$. No Brasil, os jornais vêm se modernizando neste sentido há muito tempo - desde inícios de nosso século e com um grande avanço a partir dos anos cinqüenta ${ }^{16}$, mas os resultados desta pesquisa mostram que mesmo que os leitores de camadas populares, no caso, os operários, prefiram ler estas páginas-revista, a sua quantidade ainda é pequena. Em outras palavras,

Tabela 9: Assuntos de maior interesse no jornal (leitores operários)

\begin{tabular}{|c|c|c|c|c|c|}
\hline Assuntos & Mas Ge iN & Masce id. & Fen. joy & Fen Id. & TOTAL \\
\hline Política nacional & 4 & 3 & 2 & 1 & 10 \\
\hline Política internacional & 3 & 2 & $1:$ & 1 & 7 \\
\hline $\begin{array}{l}\text { Economia, negócios, } \\
\text { investimentos }\end{array}$ & 1 & - & 1 & - & 2 \\
\hline Esportes & 5 & 8 & 1. & - & 14 \\
\hline Not. policiais & 4 & 2 & 3 & 2 & 11 \\
\hline $\begin{array}{l}\text { Variedades (quadrinhos, } \\
\text { heróscopo, fofocas de } \\
\text { artistas etc.) }\end{array}$ & 1 & - & 6 & 3 & 10 \\
\hline Editoriais & - & - & - & - & zero \\
\hline $\begin{array}{l}\text { Seção Cultural (crítica de } \\
\text { arte, cine, teatro) }\end{array}$ & 1 & - & - & - & 1 \\
\hline $\begin{array}{l}\text { Programação de } \\
\text { espetáculos e TV }\end{array}$ & 2 & - & - & - & 2 \\
\hline Coluna social & - & - & - & - & zero \\
\hline Classificados & 1 & 1 & 2 & 2 & 6 \\
\hline Seção feminina & - & - & 1 & 4 & 5 \\
\hline Outros (especificar) & $\begin{array}{c}\text { not. } \\
\text { nacional } \\
\text { manchete } \\
1\end{array}$ & - & $\begin{array}{c}\text { crônicas } \\
1\end{array}$ & $\begin{array}{c}\text { not. } \\
\text { nacionais } \\
1\end{array}$ & 4 \\
\hline Lê tudo ou quase & - & 1 & 1 & - & 2 \\
\hline $\begin{array}{l}\text { Não se aplica } \\
\text { (não lê nunca jornais) }\end{array}$ & 2 & 2 & 5 & 7 & 16 \\
\hline
\end{tabular}

$\mathrm{N}=44$ respondentes operários que dizem ler jornais, mesmo raramente.

Fonte: pergunta 79: "Qual é a parte do jornal que mais lhe interessa?"

14. ALBERT, Pierre \& TERROU, François. Histoire de la presse. Paris, PUF, 1974. Ver também, sobre esse processo па Inglaterra, WILLIAMS, Raymond. The Long Revolution. Nova York, Columbia University Press. Nos Estados Unidos as grandes alteraçōes no conteúdo dos jornais fazem-se com Hearst e Pulitzer. Ver EMERY, B. História da Imprensa nos Estados Unidos.

15. Sobre isso ver especialmente COHN Gabriel. Sociologia da Comunicaçãa: Teoria $\varepsilon$ ldeologia. São Paulo, Pioneira, 1973.

16. Ver SODRÉ, N. W. História da Imprensa no Brasil. Rio de Janeiro, Civilização Brasileira, 1966: BAHIA, Juarez. Jornal, História e Técnica São Paulo, IBRASA, 1972; GOLDENSTEIN, G. T. Do Jomalismo Politico à Industria Cultural no Brasil, São Paulo, Summus, 1987: GOLDENSTEIN, G.T Folhas ao Vento - contribuição ao estudo da indústria cultural no Brasil, USP, 1987 (mimeo). 
além de serem poucos os que têm o hábito de leitura de jornais, o material pelo qual têm maior interesse é justamente o mais pobre em termos de informação política, econômica e cultural no sentido estrito, quando comparado ao preferido pelos segmentos sociais superiores. Compram menos jornais, lêem menos, ignorando temas importantes, e formam o menor contingente de leitores da amostra. São poucos os que tiram proveito da imprensa; e, de certa maneira, absorvem sua modernidade no que ela tem de pior.

A leitura de revistas não apresentou um. padrão muito diferente do encontrado com relação à leitura de jornais, entre os operários.

Com relação a revistas semanais de atualidades, como mostra a tabela 10 , o índice de leituras operárias é mais baixo ainda do que o de leitores diários dos jornais, chegando a ser quase nulo: apenas três respondentes declararam lê-las regularmente, o que equivale a
$5 \%$ dos C's, em contraste com $43,33 \%$ dos B's e $88,33 \%$ dos A's. $76,67 \%$ dos operários disseram que não as lêem (em comparação com 26,67\% dos $B^{\prime}$ s e com $6,67 \%$ dos $A^{\prime}$ s) e $18,33 \%$ afirmaram que o fazem "de vez em quando".

O índice declarado de compra dessas revistas aparece na tabela 11. No caso dos operários, vê-se que os números são bastante coerentes com os índices declarados de leitura (ou melhor, de ausência de leitura). Observe-se, de passagem, que na classe A o volume de compras é maior que o índice declarado de leitura, e aconteceu isto no caso dos jornais também.

De um lado, o custo pode ajudar a explicar um consumo tão baixo de revistas semanais de atualidades. Em entrevistas em profundidade realizadas na etapa anterior desta pesquisa, houve menções a leituras feitas "quando se obtinha uma revista emprestada".

De outro lado, a temática de tais revistas,

Tabela 10: Hábito de ler revistas semanais de atualidades x classe

\begin{tabular}{|c|c|c|c|c|c|}
\hline & $z^{2}$ & Nằ & manalm. & $\begin{array}{l}\text { Devez } \\
\text { en auando }\end{array}$ & TOTAL \\
\hline \multirow{2}{*}{ A } & freq. & 4 & 53 & 3 & 60 \\
\hline & row $\%$ & 6,67 & 88,33 & 5,00 & 100 \\
\hline \multirow{2}{*}{ B } & freq. & 16 & 26 & 18. & 60 \\
\hline & row $\%$ & 26,67 & 43,33 & 30,00 & 100 \\
\hline \multirow{2}{*}{ C } & freq. & 46 & 3 & 11 & 60 \\
\hline & row $\%$ & 76,67 & 5,00 & 18,33 & 100 \\
\hline \multicolumn{5}{|c|}{ Total } & 180. \\
\hline
\end{tabular}

Fonte: perg. 83: "0 sr. (a) lê alguma revista semanal de atualidades? " $x$ classe

Tabela 11: Hábito de aquisiçăo de revistas semanais de atualidades $\mathrm{x}$ classe

\begin{tabular}{|c|c|c|c|c|c|c|c|}
\hline & & NSWNR & $\begin{array}{l}\text { Härocomp. } \\
\text { Hem Ass. }\end{array}$ & Assina & $\begin{array}{l}\text { Comira } \\
\text { Semanal. }\end{array}$ & $\begin{array}{l}\text { De vez } \\
\text { ema Quando }\end{array}$ & Totat \\
\hline \multirow{2}{*}{ A } & freq. & 0 & 4 & 55 & 0 & 1 & 60 \\
\hline & row $\%$ & 0 & 6,67 & 91,67 & 0 & 1,67 & 100 \\
\hline \multirow{2}{*}{ B } & freq. & 2 & 23 & 22 & 2 & 11 & 60 \\
\hline & row $\%$ & 3,33 & 38,33 & 36,67 & 3,33 & 18,33 & 100 \\
\hline \multirow{2}{*}{ c } & freq. & 3 & 47 & 2 & 1 & 7 & 60 \\
\hline & row $\%$ & 5,00 & 78,33 & 3,33 & 1,67 & 11,67 & 100 \\
\hline \multicolumn{7}{|c|}{ Total } & 180 \\
\hline
\end{tabular}

Fonte: perg. 85: "Compra ou assina alguma(s) dessas revistas? " $x$ classe 
mais voltada (embora não com exclusividade) para a informação do que para o entretenimento puro e simples, pode também ajudar a explicar a falta de consumo deste tipo de material pelos operários. Esta hipótese é congruente com os assuntos por èles preferidos nos jornais, que vimos mais acima. É congruente também com os índices mais altos de leitura declarada com relação a outros tipos de revistas, que podem ser conferidos na tabela 12. Nela se vê que o número de operários que diz que as costuma ler sobe de 3 (que lêem as revistas de atualidades) para 18, o que significa $30 \%$ dos entrevistados da classe C. Nẵo acontece o mesmo nas demais classes. $O$ número de consumidores de outras revistas ou é o mesmo ou é ligeiramente inferior ao dos leitores das revistas semanais. A comparação das tabelas 10 e 12 permite perceber isto claramente. Cabe saber então, que tipo de revistas são essas e de que elas tratam.

Mas aí a própria segmentação do mercado feita pela indústria cultural responde a questão. Os homnens lêem mais as revistas ditas masculinas, leia-se eróticas; as mulheres mencionam mais as revistas femininas de modo geral e as fotonovelas. Alguns poucos homens mencionam revistas especializadas (uma de música, duas de eletrônica, uma sobre automóveis). Registrem-se, ainda, quatro menções a revistas religiosas e quatro a infantis.

De qualquer maneira, é importante reter que $2 / 3$ dos operários não lêem nenhuma dessas revistas ou o fazem de vez em quando.

Resta ver a leitura de livros. Trata-se aqui apenas de livros que não têm ligação com o trabalho do entrevistado. De acordo com a tabela 13, os índices de leitura de livros que emergem das respostas dos operários seguem muito de perto os referentes à leitura de "outras revistas", que vimos na tabela 12 . No entanto, quando prosseguimos o questionário tentando cercar melhor esta questão, através do pedido aos respondentes operários de especificação dos gêneros e autores prediletos, a discriminação revelou-se precária e muitos entre os que tinham declarado que costumavam ler livros simplesmente não conseguiram responder a essas perguntas.

Ainda assim, cabe registrar que houve menções a romances, contos, livros religiosos, sem nenhuma tendência nítida. Entre os autores, há menções a Jorge Amado - seis - e a Agatha Christie - duas - e outros que não tiveram mais do que uma menção e que incluem de Sidney Sheldon a Clarice Lispector. Mas o forte nestas questões foram o "não sei" e o "não se aplica".

Em suma, embora a leitura tenha aparecido com certa freqüência nas mençōes espontâneas dos operários com referência ao uso de seu tempo de não trabalho, ela não emerge como atividade privilegiada de lazer neste segmento social, após uma verificação mais detalhada. Muito ao contrário, vimos que são poucos os leitores regulares de jornais e de revistas informativas e que neles se procuram mais temas de evasão e entretenimento do que informação política e econômica ou assuntos culturais no sentido estrito. Vimos também que a porcentagem de leitores cresce quando se trata de outras revistas, mas, ainda assim, não ultrapassa $30 \%$ dos entrevistados. E com relação aos livros, os indices de operários que se declararam leitores, já pequenos, não resistiram a um controle mais detalhado de suas respostas.

Estes resultados são congruentes com os obtidos em várias outras pesquisas realizadas antes da que serve de base a este trabalho, as quais, a partir de distintas perspectivas, trataram da questão da leitura neste segmento social.

Tabela 12: Hábito de leitura de outras revistas x classe

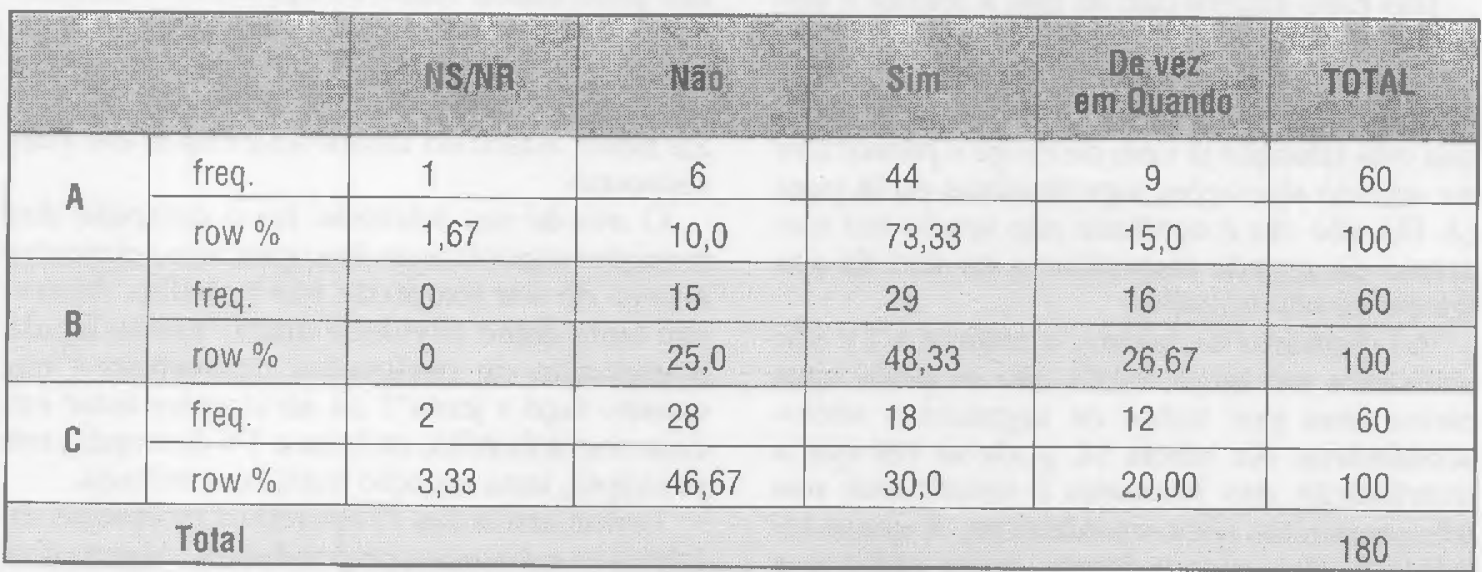

Fonte: perg. 86: "0 sr. (a) lê algum outro tipo de revista? " $x$ classe 
Tahela 13: Hábito de leitura de livros x classe

\begin{tabular}{|c|c|c|c|c|c|c|}
\hline & & MSHR & Tha & $\begin{array}{l}\text { ogvez } \\
\text { em quando }\end{array}$ & Sempre & TOTAL \\
\hline \multirow{2}{*}{ A } & freq. & 0 & 5 & 18 & 37 & 60 \\
\hline & row $\%$ & 0 & 8,33 & 30,00 & 61,67 & 100 \\
\hline \multirow{2}{*}{ B } & freq. & 1 & 12 & 22 & 25 & 60 \\
\hline & row $\%$ & 1,67 & 20,0 & 36,67 & 41,67 & 100 \\
\hline \multirow{2}{*}{ C } & freq. & 0 & 28 & 18 & 14 & 60 \\
\hline & row $\%$ & 0 & 46,67 & 30,0 & 23,33 & 100 \\
\hline \multicolumn{6}{|c|}{ Total } & 180 \\
\hline
\end{tabular}

Fonte: perg. 88: "0 sr. (a) costuma ler livros que nāo têm ligação direta com seu trabalho? "x classe

No que se refere a jornais, Leôncio Martins Rodrigues verificou, em pesquisa realizada com operários de sexo masculino em São $\mathrm{Paulo}^{77}$, que apenas $15 \%$ do total de seus entrevistados lia jornais diariamente - embora esta taxa subisse para $44 \%$ entre os operários de maior qualificação, tomados isoladamente. Em nossa pesquisa que serviu de base à tese de mestrado, nós lidamos diretamente com jornais dirigidos às camadas populares urbanas de São Paulo nas décadas de 1950 e 1960, e encontramos resultados semelhantes aos do estudo atual, no que se refere aos temas preferidos de leitura em jornais por tais leitores ${ }^{18}$. Eclea Bosi, em seu belo estudo sobre leituras de operárias ${ }^{19}$ publicado em 1972, detectou entre suas entrevistadas uma taxa de $17 \%$ de leitoras habituais de jornais. Entre outras coisas, os temas prediletos de leitura dessas entrevistadas, a preferência pelas revistas entre os meios de comunicação impressos, as dificuldades de detectar os índices de leitura efetivas de livros, são semelhantes ao que verificamos no presente trabalho.

Isto tudo sugere não só que a leitura é um hábito de parte relativamente pequena dos operários por nós entrevistados em 1984 e que ela é conduzida de modo precário, como também que esta situação já vem de longe e parece não

17. MARTINS RODRIGUES, Leôncio. Industrializaçãa e Attifudes Operárias. São Paulo, Brasiliense, 1970.

18. GOLDENSTEIN, G. T. Do Jornalismo Politico à Industria Cultural, op. cit., especialmente o capítulo "Procurando o Impacto", p.129 e seguintes.

19. BOSI, Eclea. 4. Cultura de Massa e Cultura Popular - Leituras de Operárias. Petrópolis, Vozes, 1972 unanimidade nacional. Isto era esperado. Ele não exige esforço de concentração, podendo ser ouvido ao mesmo tempo que se realizam outras atividades, não depende de alfabetização e é o mais barato dos meios de comunicaçāo de massas não impressos. Entre os operários foram arrolados nesta pesquisa 96 aparelhos domésticos de rádio (cerca de 1,5 por respondente). Há uma grande dispersão de respostas quanto às estações que ouvem. As mais mencionadas pelos operários, de qualquer maneira, foram a Globo AM e a Record AM. No conjunto da amostra, as mais mencionadas são a Eldorado FM e a Jovem Pan FM; isto mostra que se há unanimidade quanto ao ato de ouvir rádio, o mesmo não ocorre quando se considera o que é ouvido pelos operários e pelos demais segmentos sócio-econômicos. O tipo de programação preferida pelos operários e pelas demais classes também são os programas musicais e/ou de variedades. Mas a tabela 15 mostra, além disso, que as classes A e B dão importância maior aos noticiários do que a $C$, a qual, por sua vez, dá aos programas policiais um peso maior. Entre os operários, conforme tabulação manual, vêem-se ainda menções a programas de música sertaneja. Os programas de Eli Correia, Gil Gomes, Humberto Marçal, Zé Betio, Afanásio foram lembrados em suas respostas.

$\mathrm{O}$ ato de ver televisão foi o campeão das menções espontâneas dos operários referentes ao uso de seu tempo de não trabalho. Apareceu tanto como atividade única, quanto ligada à execução de ubrigações domésticas ("enquanto faço a janta") ou ao simples estar em casa com a família, embora a TV demande, em princípio, uma atenção mais concentrada.

Foram arrolados 73 aparelhos receptores de televisão entre esses respondentes. Alguns têm mais de um aparelho (a velha preto e branco e 
Tabela 14: Audiência de rádio x classe

\begin{tabular}{|c|c|c|c|c|c|}
\hline & & Nấ & $\begin{array}{l}\text { Devez } \\
\text { emiruando }\end{array}$ & Sempre & TOTAL \\
\hline \multirow{2}{*}{ A } & freq. & 1 & 9 & 50 & 60 \\
\hline & row $\%$ & 1,67 & 15,00 & 83,33 & 100 \\
\hline \multirow{2}{*}{ B } & freq. & 5 & 14 & 41 & 60 \\
\hline & row $\%$ & 8,33 & 23,33 & 68,33 & 100 \\
\hline \multirow{2}{*}{ C } & freq. & 5 & 11 & 44 & 60 \\
\hline & row $\%$ & 8,33 & 18,33 & 73,33 & 100 \\
\hline \multicolumn{3}{|c|}{ Total } & & & 180 \\
\hline
\end{tabular}

Fonte: perg. 94: "0 sr. (a) costuma ouvir rádio? " x classe

Tabela 15: Programas habitualmente ouvidos no rádio $\mathrm{x}$ classe

\begin{tabular}{|c|c|c|c|c|c|c|}
\hline Programas & & & & & & \\
\hline & $f$ & $\%$ & F & \% & F. & \%. \\
\hline Musicais/variedades & 49 & 55,06 & 48 & 66,67 & 41 & 62,12 \\
\hline Noticiário & 26 & 29,21 & 17 & 23,61 & 8 & 12,12 \\
\hline Esportes & 4 & 4,49 & 4 & 5,56 & 3 & 4,55 \\
\hline Qualquer tipo & 8 & 8,99 & 2 & 2,78 & 3 & 4,55 \\
\hline Policiais & 0 & 0,00 & 1 & 1,39 & 9 & 13,64 \\
\hline Religiosos & 0 & 0,00 & 0 & $0 ; 00$ & 1 & 1,52 \\
\hline Outros & 2 & 2,25 & 0 & 0,00 & 1 & 1,52 \\
\hline NS/NR & 0 & 0,00 & 0 & 0,00 & 0 & 0,00 \\
\hline TOTAL DE MENÇÕES & 89 & 100 & 72 & 100 & 66 & 100 \\
\hline
\end{tabular}

$N=180$ respandentes; respostas múltiplas

Fonte: perg 96: "Que tipo de programa o sr. (a) costuma ouvir no rádio? " x classe

uma colorida) e só os muito pobres não dispõem de nenhum (são poucos casos).

Mais do que pelo rádio e muito mais do que pela imprensa escrita, é pela televisão que eles se informam sobre o que acontece e é vendo televisão que se distraem e se divertem em seus momentos de descanso ou mesmo de execução paralela de alguma atividade doméstica , como dissemos. Os programas mais assistidos habitualmente, segundo disseram, são, em ordem decrescente: o jornal (o das 20:00hs, na Globo), humor, novelas e programas de auditório. Alguns desses sāo realmente os programas do chamado horário nobre, reconhecidos como os de maior audiência. Isto fica visivel quando se compara esta listagem com a dos programas mais mencionados no total da amostra. Também em ordem decrescente, são eles: o jornal, filmes e seriados, novelas, shows e musicais e humor. O jornal, as novelas e os programas de humor constam das duas listagens, como se vê.

O número de aparelhos de TV nas residências operárias no entanto, na maior parte das vezes, é apenas um e, neste caso, a programação mais assistida nem sempre é aquela de que se gosta mais, pois a TV é assistida junto com a familia em $73,3 \%$ dos casos de respondentes dessa classe (na classe B esta porcentagem cai para $53,3 \%$ dos casos e na $\mathrm{A}$ cai para $40 \%$ ) e surge a necessidade de se fazerem concessões. 
De fato houve algumas diferenças, quando os operários foram indagados sobre os programas de que mais gostavam na televisão. As mulheres falaram das novelas e programas de auditório em primeiro lugar, e dos showus, musicais e programas de humor em seguida. Os homens deram destaque aos programas de humor, ao jornal, aos filmes, aos programas de auditório e aos de esportes.

Estes dados sugerem, pois, que existe uma espécie de acordo tácito entre as famílias operárias - acordo este que se torna desnecessário à medida que aumenta a renda familiar e, com ela, o número de aparelhos receptores disponíveis em cada residência. Os jornais são assistidos mais em atenção aos homens, as novelas, mais em atenção às mulheres; e os programas de auditório e humorísticos são um campo que agrada simultaneamente aos dois sexos. Como vimos que a grande maioria dos respondentes operários assiste televisão junto com a família, se levarmos em conta os horários e a duração destes programas mais mencionados, veremos que eles dedicam realmente muitas horas à televisão.

Isto é perfeitamente coerente com as menções espontâneas freqüentes ao assistir televisão, ao ficar em casa nos momentos de não trabalho, que apareceram no início de nossa análise.

\section{FICAR EM CASA...}

Nas entrevistas em profundidade que fizemos na etapa piloto desta pesquisa, a permanência na residência fora do período de trabalho (é bom lembrar que quando falamos em trabalho estamos sempre nos referindo a trabalho remunerado) foi muito enfatizada. $\mathrm{Na}$ etapa da pesquisa propriamente dita, essa impressão pareceu ganhar mais peso ainda, com exceção das saídas para visitas a parentes.

Já vimos que pouco vão (só os mais jovens) a cinemas, teatros, shows. Concertos, nem pensar. A restaurantes também vão muito pouco: $65 \%$ dos respondentes operários não os costumam freqüuentar. A tabela 16 permite ver isto mais em detalhe. Houve apenas três respondentes operários que disseram que văo pelo menos uma vez por semana, em contraste com as respostas dos demais segmentos sócioeconômicos. A distribuição das respostas evidencia que a frequiência a restaurantes cresce junto com a posição na escala sócio-econômica. Esta, portanto, é mais una modalidade de lazer da qual os operários estão muito excluídos.

Os clubes tampouco são uma alternativa para a maioria deles, pois $76,7 \%$ dos operários não são sócios de nenhum. Na classe B, 56,7\% são sócios de algum e isto ocorre com $88,3 \%$ dos A's. Apesar disso, para $23,3 \%$ dos operários ir ao clube pode ser uma alternativa. Mas entre eles (quatorze respondentes) apenas cinco vão regularmente. Os demais o fazem só de vez em quando. Não é, portanto, uma opção importante no lazer operário, ao contrário do que ocorre com os membros das outras classes

É verdade que alguns vão a "botecos", se não vão a clubes ou a restaurantes. Mas é difícil saber exatamente quantos, porque a pergunta sobre este tópico causou algum constrangimento entre os respondentes. De qualquer maneira, $25 \%$ dos operários disseram que vão e mais $8,3 \%$ deles disseram que vão às vezes.

O "boteco" talvez seja a contrapartida popular aos restaurantes e clubes: se $56,7 \%$ dos operários disseram que não o freqüentam, esta porcentagem vai para $65 \%$ entre os B's e para $76,7 \%$ entre os $A^{\prime}$ s. Em vez da refeição ou do uísque no restaurante ou no clube, pode ser a "cervejinha no boteco". A finalidade de en-

Tabela 16: Freqüência a restaurantes à noite ou em fins de semana $x$ classe

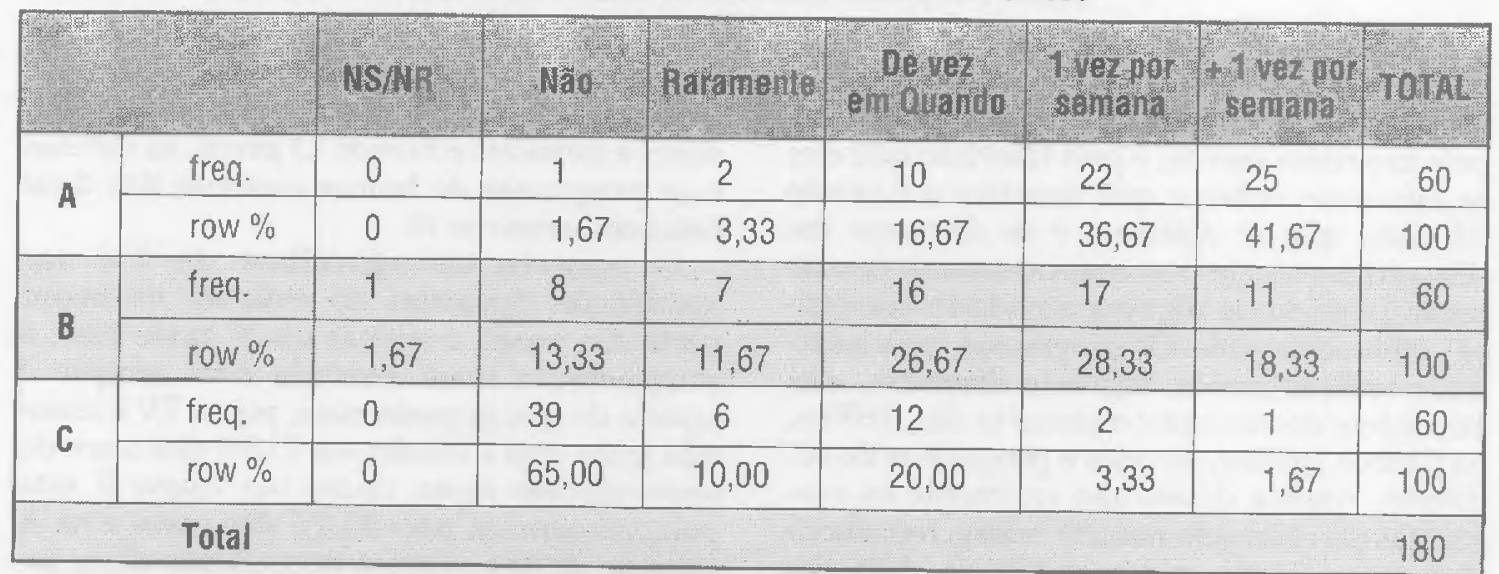

Fonte: perg. 51: " 0 sr. (a) costuma freqüentar restaurantes à noite ou em fins de semana? " $x$ classe 
contrar amigos e conversar pode ser cumprida em qualquer desses locais. E se levarmos em conta que essa atividade parece ser mais masculina, pelo menos para os homens o "boteco" pode ter alguma relevância no lazer da classe operária.

Mas o que fazem, além disso? Esportes, $23,3 \%$ dos operários os praticam (o que significa que $76,7 \%$ não o fazem). Estes esportistas são quase todos homens e jovens. No conjunto da amostra o sexo perde relevância, mas a idade nāo. Esportes e ginástica são mesmo mais apreciados pelos jovens. Mas a prática de exercícios físicos parece estar nitidamente associada à estratificação social: para os 23,3\% dos operários esportistas há $40 \%$ dos B's e $66,7 \%$ dos $A^{\prime}$ s, como se pode ver na tabela 17.

Além da diferença com relação ao número de adeptos, a estratificação pesa também na definição do significado das práticas esportivas e de exercícios físicos. A tabela 18 , sobre as razōes pelas quais se dedicavam a essas práticas, mostra que enquanto entre os operários os esportes estão associados predominantemente ao prazer e à satisfação de praticá-los, e em segundo lugar, à manutenção da saúde física e mental, à medida que se passa da base para a cúpula sócio-econômica, a importância desses dois itens se inverte e começam a ganhar peso também as razões estéticas. A idade também tem alguma influência sobre o significado atribuído aos esportes: à medida que ela avança, aumentam as preocupações com a saúde e diminuem as relacionadas ao prazer. Mas isso não se aplica aos operários, pois, como já dissemos, os esportistas desta classe são quase todos jovens. Com relação à prática de dança ou algum outro exercício físico, a participação dos operários é virtualmente nula: $95 \%$ deles não praticam nada disso.

Mas se os esportistas e dançarinos são franca minoria entre os operários, pelo menos eles vivenciam estas práticas como prazer e pronto. Sem uma preocupação maior que a de desfrutar desses momentos. O "culto ao corpo" não parece ter chegado aos operários de nossa amostra. Esta hipótese ganha mais força, especialmente em relação aos homens, quando se levam em conta outros cuidados com o corpo, voltados para a aparência física.

Entre os operários, pouco mais da metade disse que se preocupa apenas com cuidados

Tabela 17: Prática regular de esportes ou ginástica $x$ classe

\begin{tabular}{|c|c|c|c|c|}
\hline & 8 & sin & Nio & TOTAL \\
\hline \multirow{2}{*}{ A } & freq. & 40 & 20 & 60 \\
\hline & row $\%$ & 66,67 & 33,33 & 100 \\
\hline \multirow{2}{*}{ B } & freq. & 24 & 36 & 60 \\
\hline & row $\%$ & 40,00 & 60,00 & 100 \\
\hline \multirow{2}{*}{ C } & freq. & 14 & 46 & 60 \\
\hline & row $\%$ & 23,33 & 66,67 & 100 \\
\hline \multicolumn{4}{|c|}{ Total } & 180 \\
\hline
\end{tabular}

Fonte: perg. 56: "0 sr. (a) pratica esportes ou ginástica regularmente? " $x$ classe

Tabela 18: Razões pelas quais pratica esportes/ginástica $\mathrm{x}$ classe

\begin{tabular}{|c|c|c|c|c|c|c|}
\hline \multirow{3}{*}{ Razões } & \multicolumn{6}{|c|}{ CLASSE } \\
\hline & & 1 & & & & 3 \\
\hline & $\mathrm{F}$ & $\%$ & $F$ & $\%$ & $f$ & $9 \%$ \\
\hline Prazer e satisfação & 22 & 36,07 & 12 & 42,86 & 11 & 55,00 \\
\hline $\begin{array}{l}\text { Manter saúde física } \\
\text { e/ou mental }\end{array}$ & 31 & 50,82 & 14 & 50,00 & 7 & 35,00 \\
\hline Razōes estéticas & 7 & 11,48 & 1 & 3,57 & 1 & 5,00 \\
\hline Outros & 1 & 1,64 & 1 & 3,57 & 1 & 5,00 \\
\hline TOTAL DE MENÇÕES & 61 & 100 & 28 & 100 & 20 & 100 \\
\hline
\end{tabular}

Fonte: perg. 57: "Por que pratica esportes ou ginástica? " x classe 
relacionados à higiene pessoal: foram 34 respostas assim, das quais 24 masculinas; equivalem a $56,7 \%$ dos C's. A manicure e o cabeleireiro receberam o segundo maior número de menções: 21. Mas 19 delas partiram de mulheres. Se levarmos em conta que a amostra operária tem trinta respondentes de cada sexo, veremos que entre os homens desta classe, $80 \%$ disseram que cuidam apenas da higiene pessoal. Já entre as mulheres, $63,3 \%$ delas cuidam do cabelo e das unhas, além da higiene pessoal, uma porcentagem alta, sem dúvida. Registre-se ainda que as saunas, massagens e duchas, bastante mencionadas nas respostas das outras classes foram citadas por apenas dois operários (do sexo masculino). Uma visão de mundo mais tradicional e rústica pode ajudar a explicar estas respostas, talvez mais do que a própria disponibilidade de recursos materiais. Nesta visão, cuidados com a aparência física (além dos de higiene pessoal) para os homens podem chocar-se com o machismo. As mulheres cuidam muito das unhas e dos cabelos. Mas este é um hábito feminino bastante arraigado no Brasil, mesmo em cidades pequenas. Já a sauna, as massagens e as duchas parecem integrar-se mais ao universo das grandes cidades. Embora preexistam à era do "culto do corpo", são congruentes com ele e com uma sofisticação à qual os operários (pelo menos nos limites de nossa amostra) parecem ser pouco permeáveis. Juntese a isso o fato de que o significado desses cuidados com a aparência (além dos de higiene pessoal) apareceu associado primordialmente ao prazer em $60 \%$ dos casos entre os operários (são quase todos do sexo feminino) que os tomam; em $24 \%$ dos casos significam prazer e obrigação simultaneamente e somente em $12 \%$ associam-se apenas a uma obrigação (na classe A a porcentagem dos que vêem tais cuidados apenas como obrigação sobe para $20 \%$ ).
Assim como os esportes, eles se ligam mais ao prazer do que a outra preocupação com o corpo ou com a aparência. Para as mulheres eles têm uma dimensão de lazer. Os homens quase não participam dessas práticas. É possivel que, entre os operários, o cabeleireiro seja o equivalente feminino do "boteco", em termos de espaço de sociabilidade.

Os passeios ao ar livre, por sua vez, são bastante apreciados, não só pelos operários como por todas as classes. A tabela 19 mostra que quase $2 / 3$ dos operários os realizam, numa proporção que não difere muito da das outras classes. A diferença eventual é quanto à periodicidade de tais passeios. Ela é mais curta e regular nos segmentos A e B que no dos operários.

Não aprofundamos esta pergunta no questionário, mas esta diferença de periodicidade e tudo aquilo que acabamos de ver permitem, ao menos, levantar a hipótese de que o significado desses passeios não seja o mesmo em todas as classes. A proporçāo maior de freqüentadores regulares nos segmentos A e B os aproxima da prática de exercícios como o cooper, jogging etc. (o "culto ao corpo"), enquanto que o caráter mais esporádico dos passeios operários parece torná-los mais próximos de uma "ida à praça". De qualquer modo, é lazer.

O gosto pelos parques de diversões e a maneira como os freqüentam também reforça esta hipótese. $40 \%$ dos operários declararam frequientá-los e esta porcentagem cai para $26,67 \%$ nos setores médio e para $21,67 \%$ na alta burguesia. A tabela 20 mostra, além disso que há mais freqüentadores esporádicos do que constantes em todas as classes. Mas no conjunto, é um hábito mais popular. Além de irem menos que os operários, os respondentes dos demais segmentos, quando vão, levam geralmente apenas os filhos. Já os operários freqüentadores costumam ir, na maior parte

Tabela 19: Hábito de passear ao ar livre $\mathrm{x}$ classe

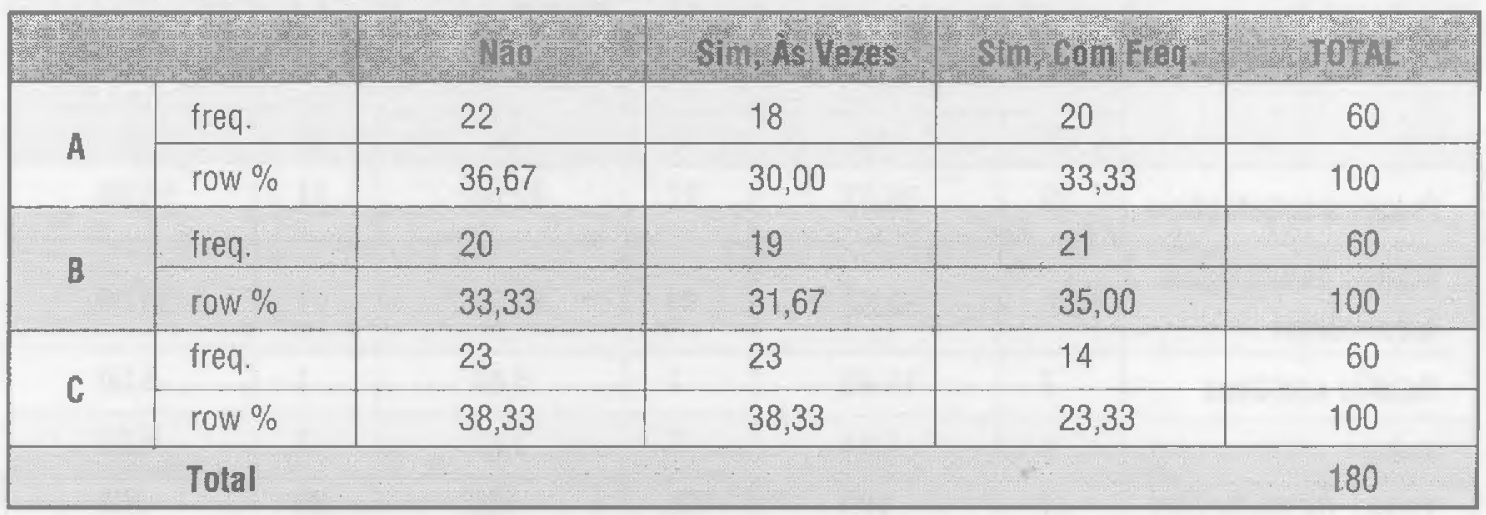

Fonte: perg. 72: "O Sr. (a) costuma passear ao ar livre? " $x$ classe 
dos casos, com toda a familia. Assim, é possivel que a conotação de lazer seja maior entre os operários, e entre os demais segmentos o caráter de obrigação esteja presente nas suas idas aos parques. É uma atividade, pois, mais popular e possivelmente mais diretamente vivida como lazer pelos operários do que pelos demais segmentos sócio-econômicos. Mas é esporádica.

De outro lado, se os operários não parecem preocupados em se tornarem atletas, $80 \%$ deles costumam assistir a jogos esportivos $(41,7 \%$ dizem assistir sempre e $38,3 \%$ de vez em quando), sem diferenças significantes por sexo ou idade. Os "esportistas passivos" proliferam também em outras classes, cujo padrão de respostas foi o mesmo dos operários. A diferença reside na maneira pela qual assistem a esses jogos. À medida que se "sobe" do segmento C para o $\mathrm{A}$, aumenta o número dos respondentes que os vão assistir in loco. Na classe operária eles sāo $15 \%$, nos setores médios são 23,3\% e na burguesia já são $38 \%$. A maioria, em qualquer dos casos, vê os jogos pela televisão e os operários fazem isto mais do que todos. Mas, assim, eles estāo em casa de novo, vendo televisão!

Além da TV, cerca de metade dos operários disse que se dedica a algum hobby. (Nas demais classes esta porcentagem deve ser maior, pois na distribuição de freqüência para o conjunto da amostra a proporção é de 60\%.) Os mais mencionados espontaneamente foram os trabalhos manuais e a leitura de "alguma coisa". Há menções também a coleções, desenhar, ouvir música, pescar, cuidar de plantas, de bichos, eletrônica, culinária e jogos esportivos. Com relação às leituras, já as analisamos. Os trabalhos manuais sāo feitos por metade dos respondentes ( $C^{\prime} s$ ), segundo disseram. (Alguns que tinham dito não ter nenhum hobby depois disseram que fazem trabalhos manuais.)
As mullheres falam de culinária, crochet, tricot, desenho, cerâmica, pintura em tecido. Os homens falam mais de trabalhos ligados a construção e consertos das casas, havendo também referências a cerâmica, costura e marcenaria (uma a cada). A finalidade com que tais trabalhos são feitos varia. A maioria os faz por prazer e isto é em todas as classes. Mas entre os operários aparecem algumas alusões a necessidade e a dinheiro como motivo, que está praticamente ausente nas outras classes.

Cabe também fazer algumas observaçōes em relação aos trabalhos de conserto das casas. Alguns operários os mencionaram na categoria de trabalhos manuais, mas muito não o fizeram. Na questão específica sobre este tópico de consertos, verificamos que quase todos os homens e cerca de metade das mulheres na classe operária costumam fazê-los (no total da amostra são $68,9 \%$ dos respondentes os que fazem).

Estas discrepâncias podem ligar-se, entre outros fatores, ao significado atribuído por cada um a tais atividades. De fato, no total da amostra, os motivos pelos quais os respondentes fazem pessoalmente esses consertos são necessidade, prazer e necessidade, prazer, nesta ordem. Na classe operária, os motivos dos homens sāo economia/necessidade, prazer, nesta ordem. O motivo alegado pelas mulheres que fazem os consertos é o de que "não tem quem faça" (elas são, na maioria desses casos, solteiras, viưvas ou de marido ausente). Só três delas disseram que gostam de fazê-los. Os consertos prendem-se, pois, mais ao universo das obrigações do que ao do prazer. Mas, para algumas pessoas, isto é lazer.

Os cuidados com os automóveis ligam-se também a este conjunto de atividades. Arrolamos 16 respondentes de classe $C$ que têm automóvel em casa, o que equivale a $26,67 \%$ deles. Os respondentes da classe A não gostam

Tabela 20: Hábito de ir a parques de diversões $\mathrm{x}$ classe

\begin{tabular}{|c|c|c|c|c|c|}
\hline & & Nac & Sim, is yores. & sim con Frey: & TOTA \\
\hline \multirow{2}{*}{ A } & freq. & 47 & 13 & 0 & 60 \\
\hline & row $\%$ & 78,33 & 21,67 & 0,0 & 100 \\
\hline \multirow{2}{*}{ B } & freq. & 44 & 11. & 5 & 60 \\
\hline & row $\%$ & 73,33 & 18,33 & 8,33 & 100 \\
\hline \multirow{2}{*}{ C } & freq. & 36 & 17 & 7 & 60 \\
\hline & row $\%$ & 60,0 & 28,33 & 11,67 & 100 \\
\hline \multicolumn{5}{|c|}{ Total } & 180 \\
\hline
\end{tabular}

Fonte: perg. 73: "0 Sr. (a) costuma ir a parques de diversões? " $x$ classe 
de lavar ou cuidar pessoalmente de seus carros, em sua grande maioria. Na classe $\mathrm{B}$, a proporção é de mais ou menos $50 \%$ dos que têm carro. Os C's gostam mais, mas quase $75 \%$ deles não tem automóvel próprio. Registre-se que os cuidados com os carros são atividades que encontram mais adeptos entre os jovens de sexo masculino.

Estas atividades (hobbies, trabalhos manuais, consertos, cuidados com os automóveis) tomadas em conjunto são difíceis de se analisar, na perspectiva de um estudo sobre lazer, e vistas "de fora", por um observador.

O primeiro problema diz respeito à sua classificação. São obrigações ou são lazer? O significado de cada uma dessas atividades pode ser múltiplo e variar de uma pessoa para outra. Aí se misturam prazer, obrigação, necessidade, utilitarismo e a preponderância eventual de um desses atributos vai variar de um caso para outro, de acordo com a(s) maneira(s) pela(s) qual(is) cada um vivencia a execução de determinada atividade. Alguns autores como Dumazedier qualificam estes tipos de atividades como semilazer, justamente porque elas se inserem numa zona cinzenta que se coloca entre o trabalho remunerado que é realizado como atividade profissional principal, $\mathrm{e}$ o lazer, no sentido mais restrito ${ }^{20}$.

E na classe operária esta zona cinzenta parece dilatar-se com relação às outras classes. Se alguém da alta burguesia resolve cuidar pessoalmente dos consertos de sua casa, faz isto por opção, pois certamente tem a alternativa de contratar outra pessoa para fazer o serviço. Um operário tem menos recursos financeiros e o conserto, então, torna-se sua obrigação. Mas nada impede que ele, apesar disto, tenha imenso prazer em realizar o referido conserto e eventualmente o vivencie como puro lazer. Algumas das obrigações domésticas femininas também podem ter esse caráter (registre-se que, em nossa amostra, apenas duas familias operárias dispunham de empregada doméstica; e não é simplesmente um problema de custos: dezesseis famílias tinham automóveis). E neste caso os fatos se complicam mais ainda.

Mais do que os operários do sexo masculino, as mulheres, especialmente as mães de família, têm um dia-a-dia constituído pelo que Pierre Naville denomina jornadas porosas ${ }^{21}$, ou seja, nelas se misturam e interpenetram constantemente as obrigações e a diversão. Há muitos exemplos: cozinhar vendo televisão; lavar a louça de um almoço de domingo, conversando com as parentes que partilharam aquela refeição; ir às compras e ver vitrines nos shoppings (mais da metade das operárias entrevistadas disse gostar); ir ao supermercado $(63,3 \%$ do total da amostra operária responderam que gostam de ir, e entre eles as mulheres gostam mais). Torna-se muito difícil classificar tais atividades em uma categoria ou em outra. $\mathrm{O}$ termo semilazer revela uma postura cuidadosa e de compromisso, mas não resolve totalmente o problema. A tentação maior é a de adotar um raciocínio de inspiração weberiana: o sujeito atribui o sentido a sua ação. Mas, assim mesmo, o sujeito pode atribuir um sentido múltiplo a ela e, neste caso, a classificação com base em um enquadramento rígido de categorias mutuamente excludentes, como parecem ser trabalho e lazer, continua problemática. $\mathrm{Na}$ análise do lazer da alta burguesia, Cecília Forjaz também constata uma interpenetração dos universos do trabalho e do lazer, ainda que ela se faça de outro modo ${ }^{22}$. Isso tudo sugere que o lazer talvez possa ser melhor compreendido quando remetido à dimensão das vivências do que quando recortado como um conjunto de práticas sociais.

Um segundo problema diz respeito ao significado mais profundo que essas atividades relatadas pelos operários podem ter, do ponto de vista social. Georges Friedmann relaciona o sentido de algumas delas, particularmente os hobbies e o bricolage a efeitos do sistema industrial de trabalho. "A insatisfação no trabalho, seja consciente ou não consciente, exerce uma ação permanente e múltipla sobre a vida fora do trabalho, posto que se traduz por fenômenos de evasão para atividades laterais" 23 . Friedmann vê nessas atividades um sentido compensatório à frustração causada ao trabalhador pelos processos "taylorizados" de trabalho nas fábricas, dizendo: "Tudo aquilo de que foram privados no trabalho: iniciativa, responsabilidades, realização (fazer um produto inteiro), os trabalhadores tentam recuperar no lazer. Durante os últimos dez anos comprovou-se um fantástico florescimento de manias, de pequenos trabalhos manuais (art and craft hobbies) aos quais se somam todos os tipos de lazer ativo, fotografia, cerâmica, eletrônica, rádio, etc." ${ }^{24} \mathrm{E}$ relaciona as características dos hobbies para prosseguir sua argumentação: "reação contra a preponderância da velocidade, do objeto estandartizado e preparado, da organização que vem 'de cima', do trabalho em cadeia, por meio da busca tenaz de realização no trabalho terminado e minucioso, livremente executado segundo um ritmo pessoal." ${ }^{25}$. Este significado do "lazer ativo" para Friedmann, contudo, só vale quando se trata do que ele entende como tal: atividades livremente escolhidas e não impostas, e realizadas a bel prazer do executante.

Dumazedier concorda com Friedmann no sentido de que tais atividades têm uma dimensão distinta das de trabalho, por serem

25. Idem, ibidem, p. 184. 
feitas por livre escolha, com ritmo próprio, com liberdade etc. Mas daí a ver um significado compensatório e resgatador do trabalhador como ser humano, parece achar que se trata de um passo grande demais. Senão vejamos o que diz, referindo-se a isto (e especificamente a Friedmann): “... no estado atual da pesquisa, todas essas idéias tocantes às relações do trabalho com o lazer não passam de hipóteses. Ainda dependem de confirmação" ${ }^{26}$. E diz mais: "As nossas observações sistemáticas nas empresas de Annecy, Valence e Lens sobre as atitudes de lazer em conexão com o grau de qualificação nos fazem crer que o lazer está longe de ser fator de equilibrio em relação às tarefas parcelares e repetidas. Seria ilusório contar com os hobbies espontâneos para compensar a pobreza das tarefas de execução. É necessária a iniciação a um estilo de vida, uma formação geral, pois, do contrário, na maior parte das vezes, ao trabalho que empobrece corresponderá um lazer da mesma natureza." 27.

Essa discussão serve se não para resolvermos o problema, para situá-lo e mostrar sua complexidade teórica. Apesar disto, tais atividades não podem ser ignoradas, pois como acabamos de ver, elas se encontram entre aquelas a que os operários que entrevistamos mais se dedicam. E com poucas exceções, registre-se, são atividades realizadas no âmbito doméstico e familiar. De novo, em casa!

\section{CONSIDERAÇ̃̃ES FINAIS}

O objetivo que tivemos nesta pesquisa não foi teórico. A falta de estudos sobre lazer no Brasil é grande e quisemos despretensiosamente e em caráter exploratório, em todas as etapas da pesquisa, fazer um recorte do conteúdo do lazer dos três segmentos sócioeconômicos já assinalados, da maneira pela qual é vivenciado e do seu significado.

Apesar disso, os resultados da pesquisa a que se refere este artigo - os relativos aos operários - bem como os de outras, mencionadas ao longo de nossa análise, mostram que, do ponto de vista conceitual, é muito difícil, quando não impossível, fazer um recorte nítido do lazer, em termos de um tempo ou de um conjunto de atividades específicos; e sugerem que talvez seja mais fecundo abordá-lo como uma dimensão das vivências do que remetê-lo ao universo das práticas sociais. Isto posto, vimos que os operários se encontram parcial ou totalmente excluídos de inúmeras alternativas de lazer existentes na cidade de São Paulo.

As festas são comemoradas de acordo com as disponibilidades financeiras, com periodicidade incerta, e quase sempre dentro de casa: a própria ou a de parentes. Férias não signifi- cam necessariamente alterações muito grandes na rotina de vida.

Alguns, aliás nunca tiveram férias. As viagens são poucas e o que mais muda é o ritmo das pessoas que têm trabalho remunerado.

Do consumo cultural erudito ou de massas, estão excluídos da maior parte do que ele tem para oferecer. Não vão a concertos, nem a teatros, poucos vão a cinemas ou shows, não lêem quase, e, quando o fazem, lêem apenas a parte mais pobre do que os veículos impressos trazem. Não vão a restaurantes, não são sócios de clubes, em sua maioria.

Não praticam esportes, não cuidam do corpo nem da aparência, a não ser no caso das mulheres e de cuidados mínimos e tradicionais. Não dançam, não tocam instrumentos musicais. Esta exclusão é que atinge a maior parte dos respondentes.

O que fazem eles em seus momentos de não trabalho remunerado?

Boa parte do tempo ficam em casa. Dedicamse a obrigações domésticas diversas (algumas delas implicam em sair, como é o caso das compras), fazem trabalhos manuais, alguns como hobby, outros como obrigação, que permanecem na zona cinzenta do semilazer, se usarmos a conceituação de Dumazedier. Ouvem discos, fitas, rádio, assistem televisão, conversam com os vizinhos. Recebem e fazem visitas. Fazem tudo isso em meio a uma jornada que, especialmente no caso feminino, é informe, sem limites definidos, porosa. Não é, pois, casual, que um dos significados atribuídos ao trabalho pelos respondentes operários seja o de algo que "envolve tudo". O lazer imiscui-se no trabalho e nas obrigações, sem um tempo ou um conjunto de práticas que o recortem claramente. Até no trabalho remunerado a dimensão de lazer é introduzida, por vezes, mormente entre as mulheres. Uma volta até a praça ou um passeio ao ar livre, uma eventual ida ao parque de diversões, às vezes um baile ou um cinema para os mais jovens, um papo no boteco para os homens: "O mais é ficar em casa mesmo". "Sem fazer nada".

Seja pela presença de traços culturais rurais que dificultam a absorção de certas práticas de uso do tempo livre disponíveis nas grandes cidades industrializadas, seja pela falta de acesso econômico ou educacional, seja, enfim, pelo cansaço físico ou pela própria exigüidade de um tempo inteiramente livre, o leque de alternativas do lazer entre os operários, pelo menos nos limites de nossa pesquisa, é um leque quase fechado. Configura um mundo pequeno, que reflete uma vida menor, a despeito dos fragmentos de prazer que dela consigam retirar ${ }^{28} . \square$
26. DUMAZEDIER, Joffre. "Trabalho e Lazer". In: FRIEDMANN, G. \& NAVILLE, Pierre (orgs.) Tratado de Sociologia do Trabalho. Op. cit., p.414.

27. Idem, ibidem, p. 413

28. Aproveito para reiterar meus agradecimentos ao Núcleo de Pesquisas e Publicacões - NPP da EAESP/FGV que financiou a pesquisa que serviu de base a este artigo. 